\title{
Photocatalytic Lime Render for Indoor and Outdoor Air Quality Improvement
}

\author{
José Antonio Ibáñez Gómez ${ }^{1}{ }^{\oplus}$, Andrea Giampiccolo ${ }^{2}\left(\mathbb{D}\right.$, David Maria Tobaldi ${ }^{3,4}{ }^{\circledR}$, Sabine Mair ${ }^{5}$, \\ Carla Forbela da Silva ${ }^{2}{ }^{\circ}$, Maria Casado Barrasa ${ }^{6}$, Daniel Maskell $\left.{ }^{2}{ }^{(}\right)$, Martin Philip Ansell ${ }^{2}{ }^{(1)}$,

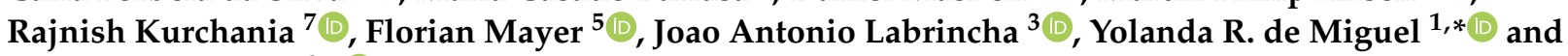 \\ Richard James Ball ${ }^{2, *(\mathbb{D}}$
}

check for

updates

Citation: Ibáñez Gómez, J.A.; Giampiccolo, A.; Tobaldi, D.M.; Mair, S.; da Silva, C.F.; Barrasa, M.C.; Maskell, D.; Ansell, M.P.; Kurchania, R.; Mayer, F.; et al. Photocatalytic Lime Render for Indoor and Outdoor Air Quality Improvement. Catalysts 2021, 11, 296. https://doi.org/ $10.3390 /$ catal11030296

Academic Editors: Magdalena Janus and Ewa Kowalska

Received: 23 December 2020

Accepted: 18 February 2021

Published: 25 February 2021

Publisher's Note: MDPI stays neutral with regard to jurisdictional claims in published maps and institutional affiliations.

Copyright: (C) 2021 by the authors. Licensee MDPI, Basel, Switzerland. This article is an open access article distributed under the terms and conditions of the Creative Commons Attribution (CC BY) license (https:// creativecommons.org/licenses/by/ $4.0 /)$.
1 TECNALIA, Basque Research and Technology Alliance (BRTA), Parque Tecnológico de Bizkaia, Astondo Bidea, Edificio 700, 48160 Derio, Spain; joseantonio.ibanez@tecnalia.com

2 BRE Centre for Innovative Construction Materials, Department of Architecture and Civil Engineering, University of Bath, Claverton Down, Bath BA2 7AY, UK; andrea.giampiccolo89@gmail.com (A.G.); C.F.daSilva@bath.edu (C.F.d.S.); dm252@bath.ac.uk (D.M.); mssmpa@bath.ac.uk (M.P.A.)

3 Department of Materials and Ceramic Engineering, CICECO-Aveiro Institute of Materials, Campus Universitário de Santiago, University of Aveiro, 3810-193 Aveiro, Portugal; david.tobaldi@ua.pt (D.M.T.); jal@ua.pt (J.A.L.)

4 CNR Nanotec, Campus Ecoteckne, Institute of Nanotechnology, 73100 Lecce, Italy

5 Fraunhofer Institute for Building Physics, Holzkirchen Branch, Fraunhoferstr. 10, 83626 Valley, Germany; sabine.mair@ibp.fraunhofer.de (S.M.); florian.mayer@ibp.fraunhofer.de (F.M.)

6 ACCIONA Construcción Technology and Innovation Centre, C/Valportillo II, 8, 28108 Alcobendas, Spain; auroramaria.casado.barrasa@acciona.com

7 Functional Nanomaterials Laboratory, Department of Physics, Maulana Azad National Institute of Technology (MANIT), Bhopal 462003, India; rkurchania@gmail.com

* Correspondence: yolanda.demiguel@tecnalia.com (Y.R.d.M.); r.j.ball@bath.ac.uk (R.J.B.)

\begin{abstract}
This article reports a novel photocatalytic lime render for indoor and outdoor air quality improvement that is composed of a lime binder and doped $\mathrm{TiO}_{2}\left(\mathrm{KRONOClean} 7000^{\circledR}\right)$ nanoparticles. These nanoparticles were distributed throughout the bulk of the finishing render, instead of as a thin coating, thus ensuring the durability of the photocatalytic properties upon superficial damage. The physical properties of these renders were not affected by the addition of nanoparticles except in the case of surface area, which increased significantly. In terms of their photocatalytic activity, these novel lime renders were shown to degrade up to $12 \% \mathrm{NO}_{\mathrm{x}}$ under UV light and up to $11 \%$ formaldehyde under visible light.
\end{abstract}

Keywords: photocatalytic; $\mathrm{TiO}_{2}$ nanoparticles; UV and visible light; lime render; air purification; $\mathrm{NO}_{x}$; formaldehyde

\section{Introduction}

Buildings account for $40 \%$ of the total energy consumption in Europe [1-4]. The current need for a reduction in total energy consumption and the resulting demand for more energy-efficient buildings through increased air-tightness pose a series of technological challenges including those related to ensuring indoor air quality [5,6]. In particular, it has been shown that volatile organic compound (VOC) pollutants can build up in the interior of these buildings due to the significantly reduced ventilation rates [3,7-9]. Poor quality of indoor air is linked to a phenomenon known as sick building syndrome (SBS), which is generally identified by irritation to different mucosae and skin together with general sickness symptoms that can be correlated to the amount of time spent indoors [10,11].

Nowadays, adsorption, electrochemical oxidation processes, and filtration are the most commonly employed methods for the reduction and removal of air pollutants [12-14]. However, these approaches involve physical removal, thus necessitating replacement, 
cleaning, and lastly disposal of any consumable items such as filters. The additional cost associated with these operations is often considered a drawback. By contrast, the mineralization of said VOC pollutants into non-hazardous or at least less dangerous compounds shows promise as a more viable solution for removal $[15,16]$.

Therefore, researchers are now developing new construction materials (particularly for use in the interior of energy-efficient buildings) that degrade, by means of photocatalysis, the concentration of harmful VOCs, such as formaldehyde, in air [17-20].

Since Honda and Fujishima [21,22] discovered the photocatalytic (PC) properties of titanium dioxide $\left(\mathrm{TiO}_{2}\right)$ for water splitting, strands of research have developed concerned with the direct application of PC particles to improve the quality of indoor air [23-27].

The large-scale use of $\mathrm{TiO}_{2}$ can be attributed to its favorable cost versus photocatalytic activity ratio, non-toxicity, ease of extraction and diversity in synthesis [28], and modification methods [29]. $\mathrm{TiO}_{2}$ is photocatalytically active within the ultraviolet (UV) range of the electromagnetic spectrum due to its wide band gap of $3.2 \mathrm{eV}$. However, it is unable to utilize the full solar spectrum where the UV range counts for only $5 \%$ [30]. This is often considered to be the major drawback of $\mathrm{TiO}_{2}$, especially for internal use, as the ability of pure $\mathrm{TiO}_{2}$ to neutralize significant proportions of contaminants in the indoor environment is greatly reduced. Strategies to enhance the photocatalytic performance of $\mathrm{TiO}_{2}$ involves modification by various methods including doping with noble metals, transition metals, and non-metallic elements [31] combining with graphene [32], and the production of reduced $\mathrm{TiO}_{\mathrm{n}}(1<\mathrm{n}<2)$ sub-oxide phases [33]. Amongst these methods, Hermann showed that doping with transition metals is ineffective because of an increase in electron-hole recombination [34]. In contrast, noble metal modification and doping of $\mathrm{TiO}_{2}$ with anions were more effective methods for harvesting visible-light [35-37]. The former method is based on the surface plasmon resonance (SPR) phenomenon of noble metals [38], and the latter method has been attributed to the presence of a foreign element in the lattice, leading to the formation of an additional electronic state in the band gap [39]. This allows electronic transitions to be initiated by visible light, improving the PC performance [29]. In fact, the authors have recently reported a study on the photocatalytic activity of modified $\mathrm{TiO}_{2}$ under indoor lighting conditions [40-42]. Other strategies to improve the absorption of visible light foresee the coupling of two or more semiconductor materials [43], which is outside the scope of the present work.

$\mathrm{TiO}_{2}$ is fully compatible with traditional construction materials [44], so its long-time adoption in combination with building materials is no surprise at all. The literature reports the application of $\mathrm{TiO}_{2}$ on the surface of a wide range of building materials [45] for both interior and exterior use, including heavy clay materials [46], architectural stones [47], wall papers [48], and mortars (sensu lato) [49,50].

Extensive research $[51,52]$ has explored the formulation of mortars containing pure $\mathrm{TiO}_{2}$ in the form of nanoparticles (NPs) for improving the outdoor environment through the degradation of pollutants. However, this research mainly exploited PC activity using the UV portion of the solar irradiation and $\mathrm{NO}_{x}$ as model pollutants [52,53]. For instance, Park et al. investigated the $\mathrm{NO}_{x}$ removal of mortar mixed with $\mathrm{TiO}_{2}$ using a UVA lamp [54]. Vieira et al. incorporated a commercial nano- $\mathrm{TiO}_{2}$ (Evonik-previously Degussa, P25) into mortars and evaluated their PC activity against $\mathrm{NO}_{\mathrm{x}}$, using artificial solar light irradiation [55]. In addition, Lucas and co-workers tested $\mathrm{PC}$ activity against the $\mathrm{NO}_{\mathrm{x}}$ degradation of mortars containing $\mathrm{P} 25 \mathrm{TiO}_{2}$ using a lamp simulating solar radiation containing a UVA component [56]. Other research groups used organic dyes such as methylene blue or rhodamine $\mathrm{B}$ to monitor the $\mathrm{PC}$ activity of $\mathrm{TiO}_{2}$-based mortars using UV lamps as the light source [56,57].

In this work, we report the use of nanotechnology in the development of a novel photocatalytic lime render with an aim to improve indoor air quality through the breakdown of formaldehyde $[58,59]$ as well as outdoor air quality by $\mathrm{NO}_{x}$ abatement. Lime-based mortars and renders exhibit a number of important advantages over more commonly used cement-based materials such as vapor permeability and the ability to accommodate 
movement [60-65]. Their hardening over months or years by carbonation contributes to these properties along with the ability to self-heal (due to the limited solubility of calcium carbonate), which may enhance a long-term mechanical bonding with embedded nanoparticles [66-70]. Doped KRONOClean7000 ${ }^{\circledR}$ nanoparticles were selected in this study due to their suitability in terms of photocatalytic activity (under UV and visible light) as well as their commercial availability and potential for scale-up and real-scale use in buildings. Herein, we present a detailed account of the preparation of these novel photocatalytic lime renders, as well as their physical and chemical characterization and their photocatalytic activity in terms of indoor $(\mathrm{VOC})$ and outdoor $\left(\mathrm{NO}_{\mathrm{x}}\right)$ air purification, under visible and UV light, respectively. In conclusion, in this study, we show that a new generation of lime-based construction materials is now available for air quality improvement both in the interior and exterior of buildings.

\section{Results and Discussion}

\subsection{Aesthetics: Color Variation}

The color of the lime render is often of importance to the end user, and for this reason, the color variation of the test specimens was evaluated. Photographs of the macroscopic appearance of the photocatalytic samples ETDK2, ETDK3, and ETDK5 are compared to the reference sample ETD in Figure 1.

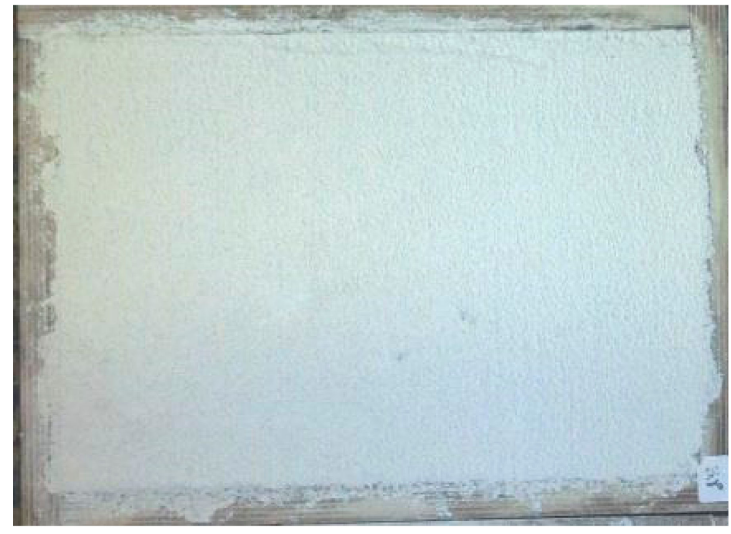

(a)

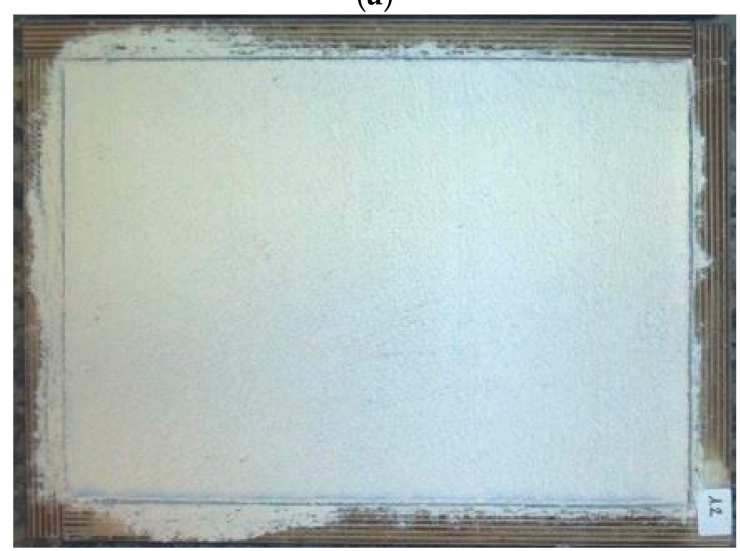

(c)

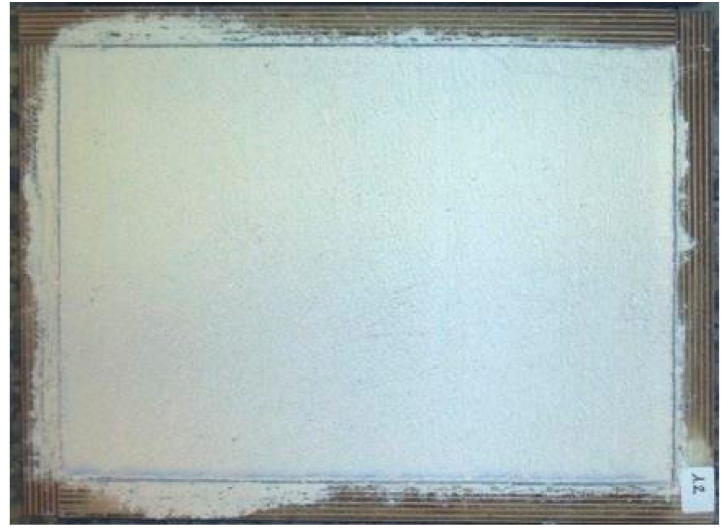

(b)

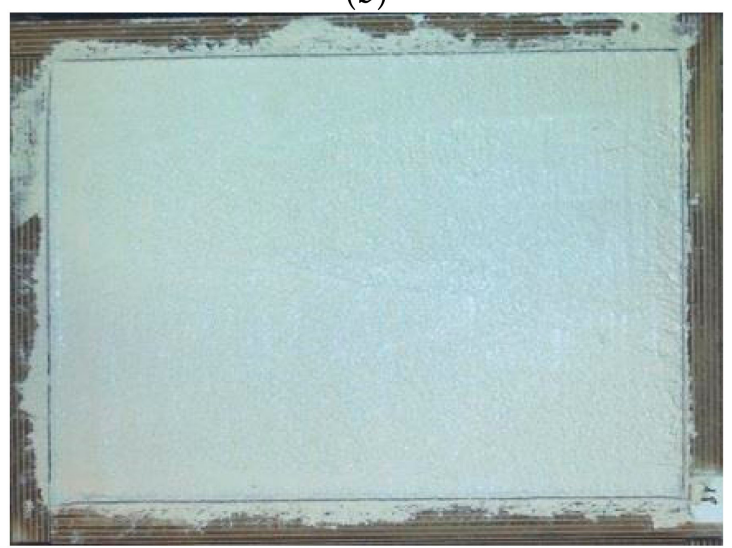

(d)

Figure 1. Photographs of the three photocatalytic samples and the ETD reference sample as defined in 3.1 of the Experimental section: (a) ETD; (b) ETDK2; (c) ETDK3; (d) ETDK5.

Color variation is represented using the CIELAB [71] color space described by three values $\mathrm{a}^{*}, \mathrm{~b}^{*}$, and $\mathrm{L}^{*}$ that describe all perceivable colors. The difference in color is achieved by comparison between sample values $\left(\mathrm{L}_{2}{ }^{*}, \mathrm{a}_{2}{ }^{*}\right.$, and $\left.\mathrm{b}_{2}{ }^{*}\right)$ and a control $\left(\mathrm{L}_{1}{ }^{*}, \mathrm{a}_{1}{ }^{*}\right.$, and $\left.b_{1}{ }^{*}\right)$, which in this case was ETD. $\Delta E^{*}$ is calculated using Equation (1) as reported by 
Sharma et al. [71]. When the value of $\Delta \mathrm{E}^{*}$ is over 2.3, it corresponds to a noticeable difference.

$$
\Delta \mathrm{E}^{*}=\sqrt{\left(\mathrm{L}_{2}^{*}-\mathrm{L}_{1}^{*}\right)^{2}+\left(\mathrm{a}_{2}^{*}-\mathrm{a}_{1}^{*}\right)^{2}+\left(\mathrm{b}_{2}^{*}-\mathrm{b}_{1}^{*}\right)^{2}},
$$

The data from Table 1 imply that the color change attributed to the presence of K7000 nanoparticles inside and on the surface of the photocatalytic mortar is not significant enough to be noticeable to the naked eye. Indeed, $\Delta \mathrm{E}$ values $1<\Delta \mathrm{E}<2$ mean that a difference in color can only be perceived by an experienced observer [72].

Table 1. Color CIELAB parameters ( $\Delta \mathrm{E}^{*}$ values over 2.3 correspond to a noticeable difference).

\begin{tabular}{cccccc}
\hline Sample & $\mathbf{L}^{*}$ & $\mathbf{a}^{*}$ & $\mathbf{b}^{*}$ & $\boldsymbol{\Delta E}^{*}$ & Noticeable Difference \\
\hline ETD & 90.07 & 0.14 & 4.37 & 0 & $\mathrm{n} / \mathrm{a}$ \\
ETDK2 & 91.16 & 0.11 & 4.17 & 1.11 & No \\
ETDK3 & 91.51 & 0.18 & 4.03 & 1.48 & No \\
ETDK5 & 90.81 & 0.26 & 4.46 & 0.76 & No \\
\hline
\end{tabular}

\subsection{Mineralogy}

X-Ray Diffraction (XRD) analyses determined that the cured reference Tradical Décor lime render (ETD) is composed mainly of quartz $\left(\mathrm{SiO}_{2}\right)$ accompanied by calcite $\left(\mathrm{CaCO}_{3}\right)$. Minor amounts of Portlandite $\left(\mathrm{Ca}(\mathrm{OH})_{2}\right)$, vaterite $\left(\mathrm{CaCO}_{3}\right)$, aragonite $\left(\mathrm{CaCO}_{3}\right)$, and rutile $\left(\mathrm{TiO}_{2}\right)$ were also detected as reported in Figure 2. The presence of Portlandite implies that full carbonation of the lime was not reached when analyses were performed after 28 days. This is quite common in limes where carbonation takes place over a period of time ranging from a few weeks to several years [73]. The rutile $\mathrm{TiO}_{2}$ detected in the XRD patterns comes from the original Tradical Décor reference sample (ETD) and is present in the material, as it is needed for aesthetic purposes as a whitener (pigment). The addition of K7000 nanoparticles to the renders (ETD2, ETDK3, and ETDK5) did not lead to measurable changes in the XRD pattern. Hence, the reflection at a $2 \theta$ value of $25.5^{\circ}$ which can be attributed to the anatase structure within the K7000 was not detected, this is likely because even at $5 \mathrm{wt} \%$ addition this was under the detection limit of that technique.

\subsection{SEM Inspection of Lab-Scale Formulated Lime Renders}

The cured Tradical Décor reference sample (ETD) has a smooth surface (Figure 3a) but when examined by Scanning Electron Microscopy (SEM) at high magnification (Figure 3b), the surface is perceived to be nodular and rough with abundant irregular pores. Energy Dispersive $\mathrm{X}$-ray (EDX) analysis (Figure 3c-e (maps) and $\mathrm{f}$ (spectrum)) shows that this material contains mainly $\mathrm{Ca}, \mathrm{Si}, \mathrm{O}, \mathrm{C}$, and Ti. Other minor elements $(\mathrm{K}, \mathrm{S}, \mathrm{Al}$, and $\mathrm{Na}$ ) are also found. This composition agrees with the mineralogical analysis. Figure $3 \mathrm{c}$ shows that Ti is already present in the commercial Tradical Décor product and is uniformly distributed throughout the lime render sample. EDX maps in Figures 3c-e and 4c-e correspond to the respective areas in Figures 3a and 4a.

SEM inspection of the three Tradical Décor lime renders with added K7000 nanoparticles (ETDK2, ETDK3, and ETDK5) shows that the original microstructure of the reference lime render (ETD) is preserved. Images from ETDK3 are shown in Figure 4. Accordingly, the surface of these samples is smooth (Figures $3 a$ and $4 a$ ), with numerous nodules and irregular pores that add micro-roughness. These materials also contain mainly $\mathrm{Ca}, \mathrm{Si}, \mathrm{O}$, and $\mathrm{C}$ (plus $\mathrm{Ti}, \mathrm{K}, \mathrm{S}, \mathrm{Al}$, and $\mathrm{Na}$ as minor elements). This composition agrees with the mineralogical results. EDX analysis shows that the titanium present in all these samples has a uniform distribution. It is not possible to distinguish the distribution of the added $\mathrm{TiO}_{2}$ (K7000) because its EDX footprint is identical to that of the titanium in the Tradical Décor sample (Figures $3 \mathrm{c}$ and $4 \mathrm{c}$ ). However, from EDX analysis, it can be seen that the intensity of the Ti peak grows as the amount of K7000 is increased (Figures $3 \mathrm{f}$ and $4 \mathrm{f}$ ). 


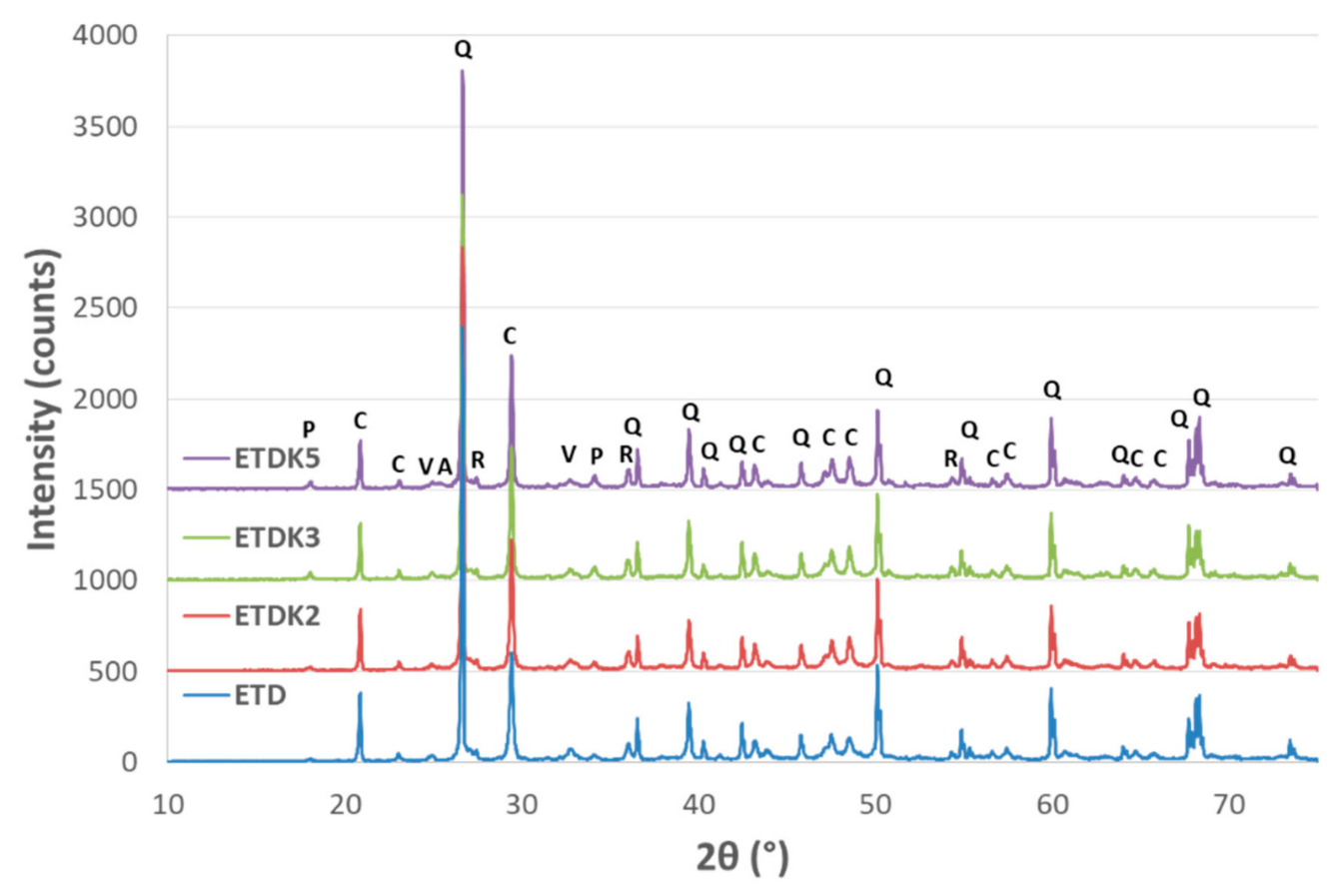

(a)

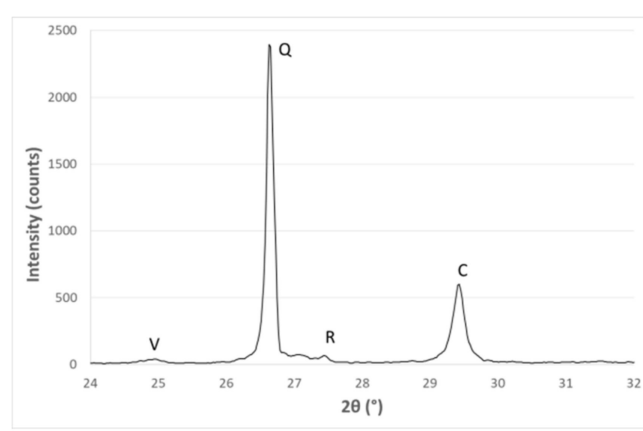

(b)

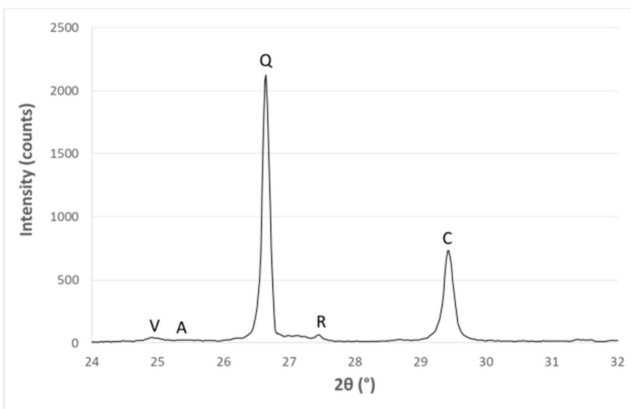

(d)

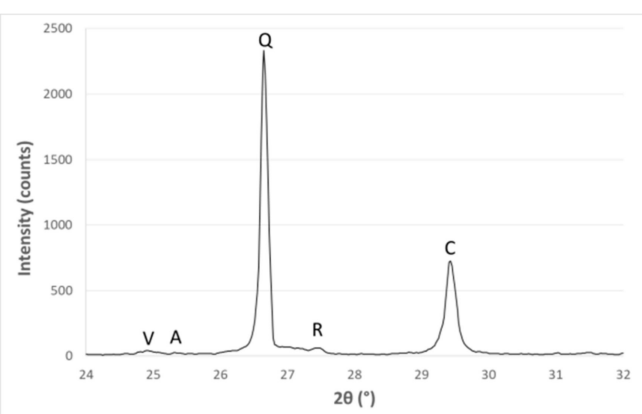

(c)

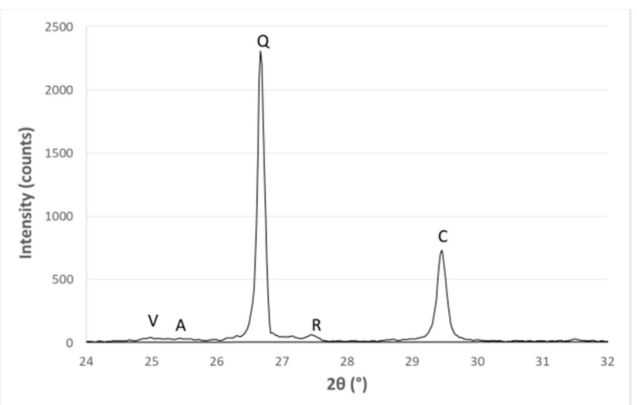

(e)

Figure 2. (a) XRD pattern of the cured reference Tradical Décor lime render (ETD), ETDK2, ETDK3, and ETDK5; (b) Zoomed XRD pattern of ETD; (c) Zoomed XRD pattern of ETDK2; (d) Zoomed XRD pattern of ETDK3; (e) Zoomed XRD pattern of ETDK5 in the region where an anatase peak would occur. Labels: A-Anatase; C-Calcite; P-Portlandite; Q-Quartz; R-Rutile; V-Vaterite. ETD, ETDK2, ETDK3, and EDTK5 correspond to the percentage of K7000 incorporated into the lime render $(0,2,3$ and $5 \mathrm{wt} \%$ respectively). 


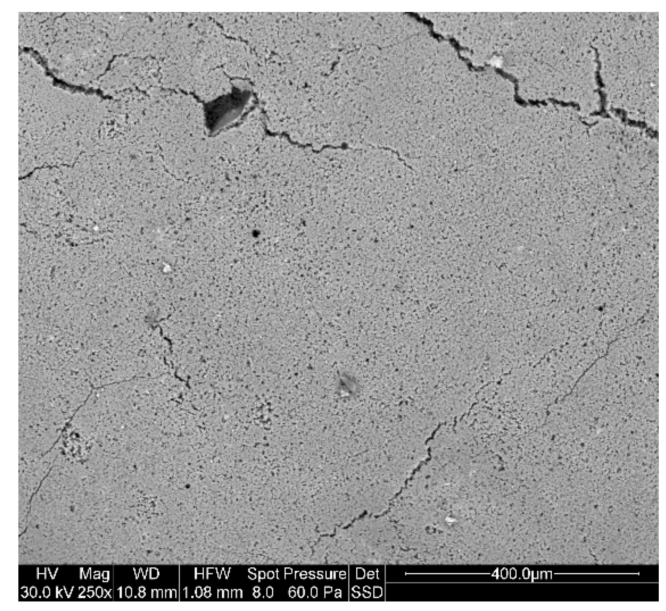

(a)

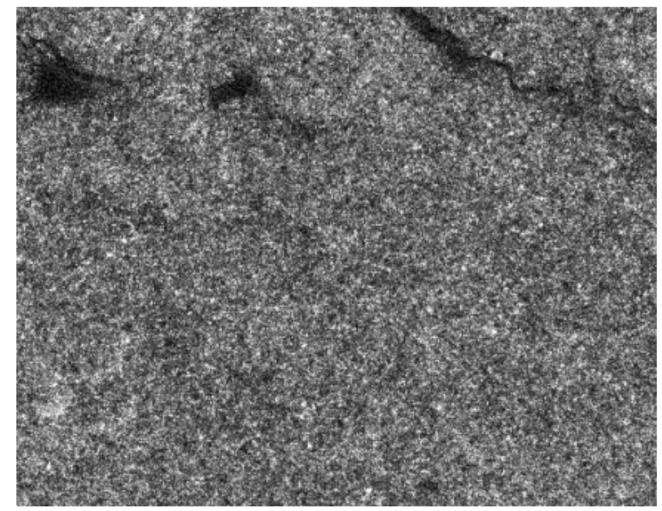

(c)

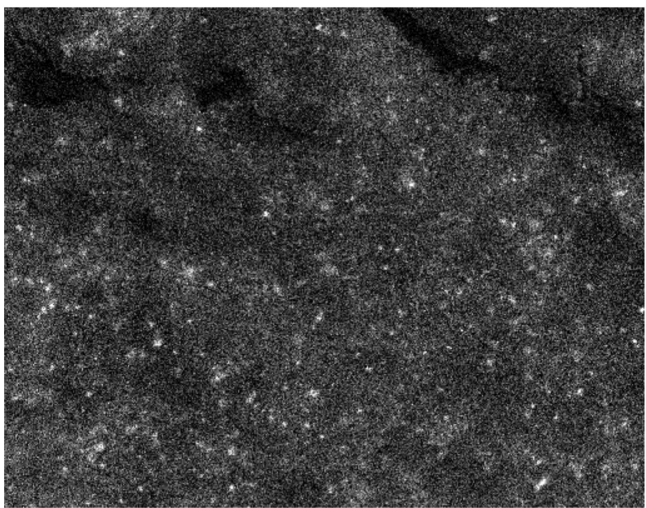

(e)

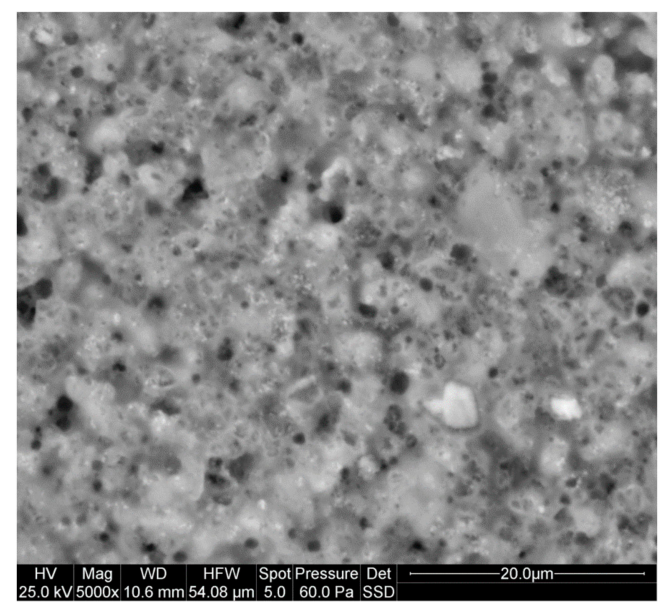

(b)

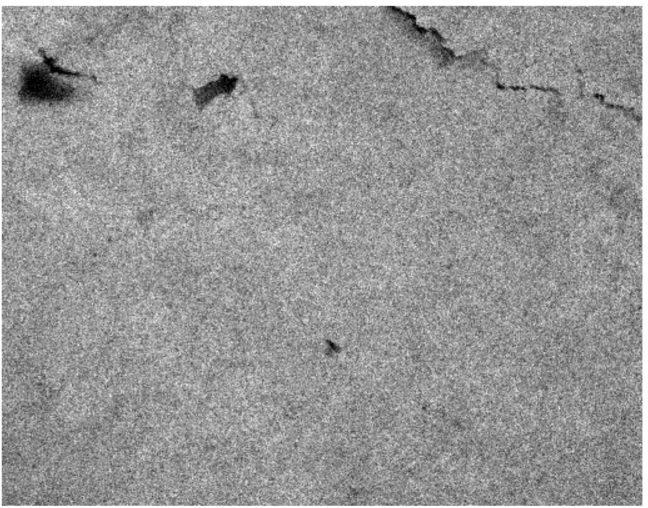

(d)

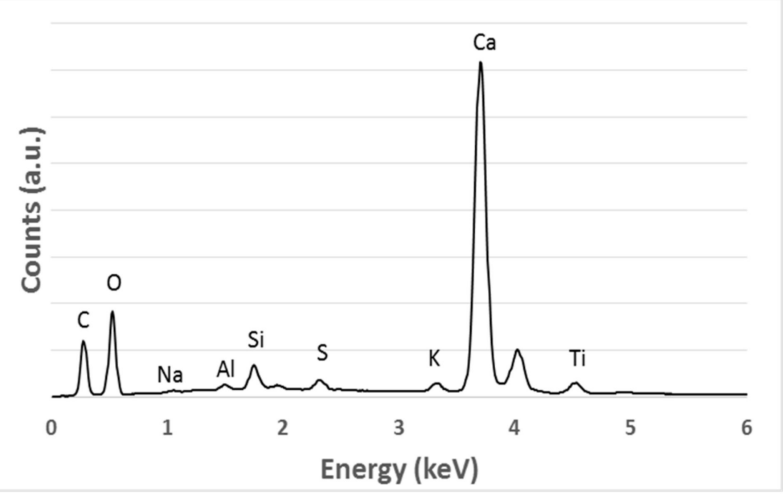

(f)

Figure 3. (a) SEM image showing the reference sample (ETD) on the surface (horizontal field of view $1.08 \mathrm{~mm}$ ); (b) SEM image showing a detailed view (horizontal field of view $54 \mu \mathrm{m}$ ) of the reference sample (ETD); (c) Energy dispersive X-ray (EDX) map reporting titanium distribution in the ETD sample; (d) EDX map reporting calcium distribution in the ETD sample; (e) EDX map reporting silica distribution in the ETD sample; (f) EDX spectrum of the surface of ETD. All EDX maps correspond to the area in (a). 


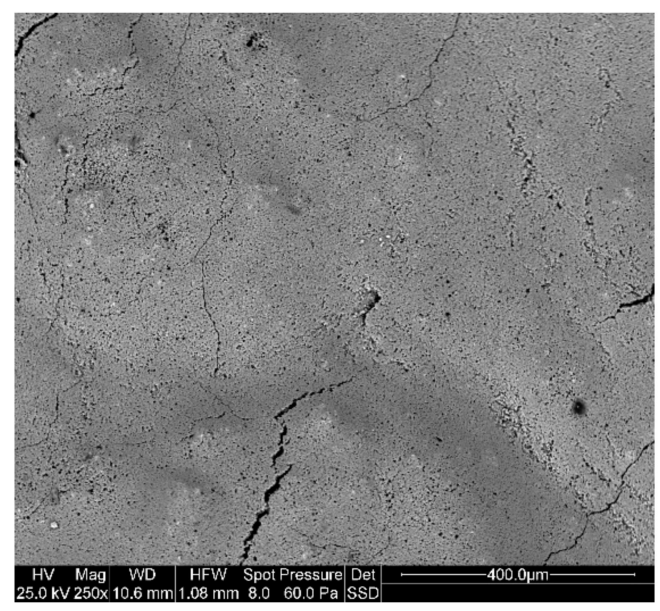

(a)

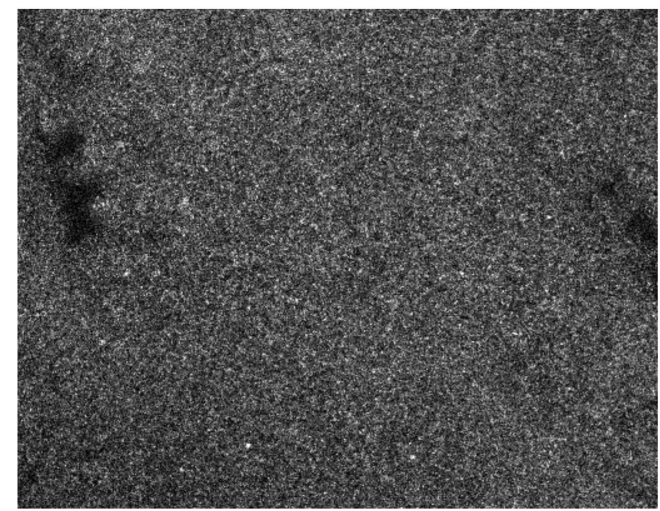

(c)

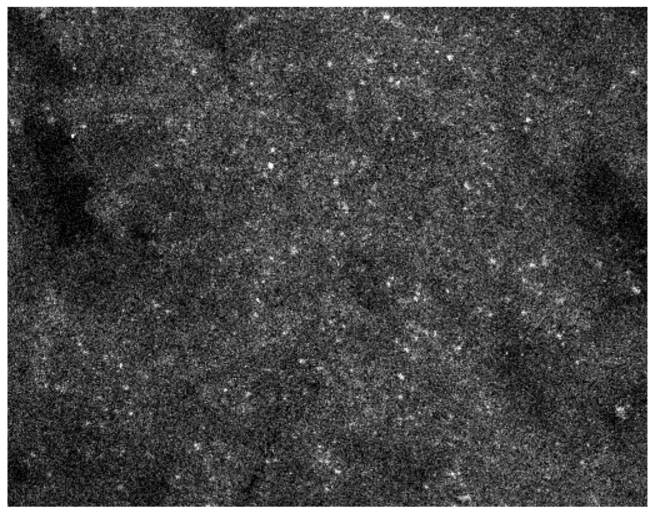

(e)

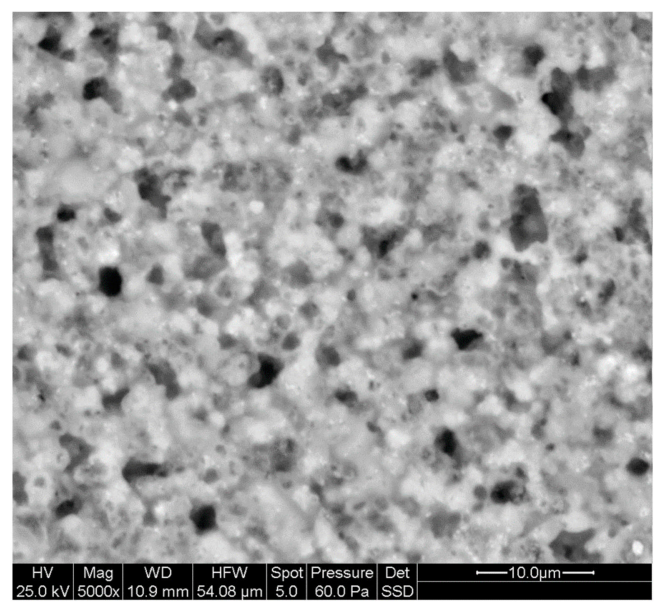

(b)

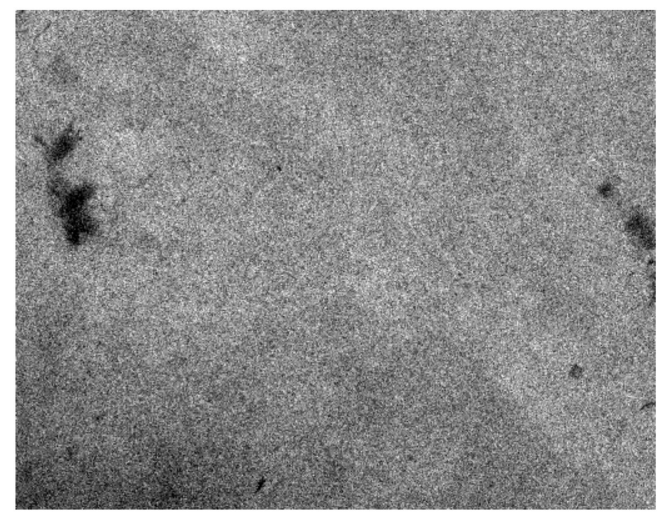

(d)

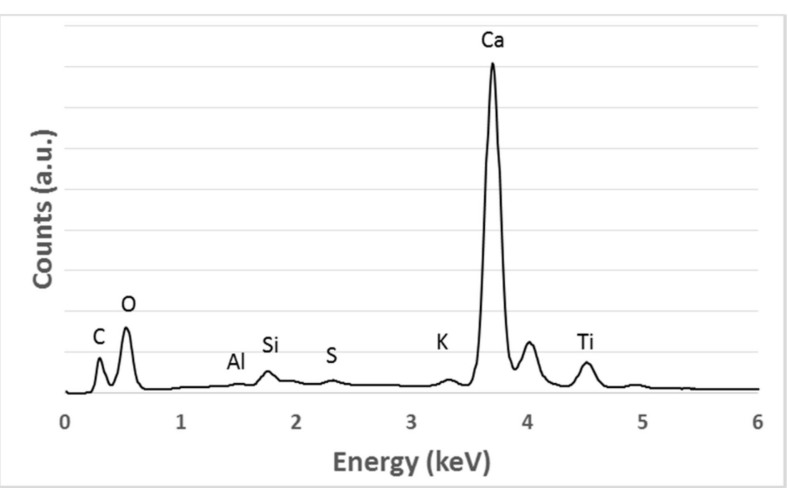

(f)

Figure 4. (a) SEM image showing Tradical decor mortar with 3\% K7000 (ETDK3) on the surface (horizontal field of view $1.08 \mathrm{~mm}$ ) of the reference sample; (b) SEM image showing a detailed view (horizontal field of view $54 \mu \mathrm{m}$ ) of the ETDK3 sample; (c) EDX map reporting titanium distribution in the ETDK3 sample; (d) EDX map reporting calcium distribution in the ETDK3 sample; (e) EDX map reporting silica distribution in the ETDK3 sample; (f) EDX spectrum of the surface of ETDK3. All EDX maps correspond to the area in (a).

\subsection{Mercury Intrusion Porosimetry of the Lime Renders}

The porosity, density, average pore size, and pore distribution of the four Tradical Décor-based lime renders was measured by mercury intrusion porosimetry, the results of which are presented in Table 2. 
Table 2. Formulated lime renders: Mercury porosimetry analysis results.

\begin{tabular}{ccccc}
\hline Sample & $\begin{array}{c}\text { Porosity } \\
\mathbf{( \% )}\end{array}$ & $\begin{array}{c}\text { Skeletal } \\
\left(\mathbf{g} / \mathbf{c m}^{\mathbf{3}}\right)\end{array}$ & $\begin{array}{c}\text { Bulk } \\
\left(\mathbf{g} / \mathbf{c m}^{\mathbf{3}}\right)\end{array}$ & $\begin{array}{c}\text { Average Pore Ø } \\
(\boldsymbol{\mu m})\end{array}$ \\
\hline ETD & 29 & 2.5 & 1.8 & 1.0 \\
ETDK2 & 30 & 2.5 & 1.7 & 0.9 \\
ETDK3 & 30 & 2.5 & 1.7 & 0.9 \\
ETDK5 & 33 & 2.5 & 1.7 & 0.8 \\
\hline
\end{tabular}

The reference sample (ETD) has a porosity of $29 \%$ and an average pore size of $1.0 \mu \mathrm{m}$. The K7000 nanoparticle-containing renders have different porosity values. In the case of ETDK2 and ETDK3 (2 and $3 \mathrm{wt} \% \mathrm{~K} 7000$ ), the porosity is barely changed with respect to the blank sample (ETD), but in the case of ETDK5 (5 $\mathrm{wt} \% \mathrm{~K} 7000)$, an increase in porosity from $29 \%$ to $33 \%$ is observed. This porosity increase is coupled with a reduction of the average pore size (from $1.0 \mu \mathrm{m}$ for ETD to $0.8 \mu \mathrm{m}$ for ETDK5), as can be seen in Table 2 and Figure 5 below.

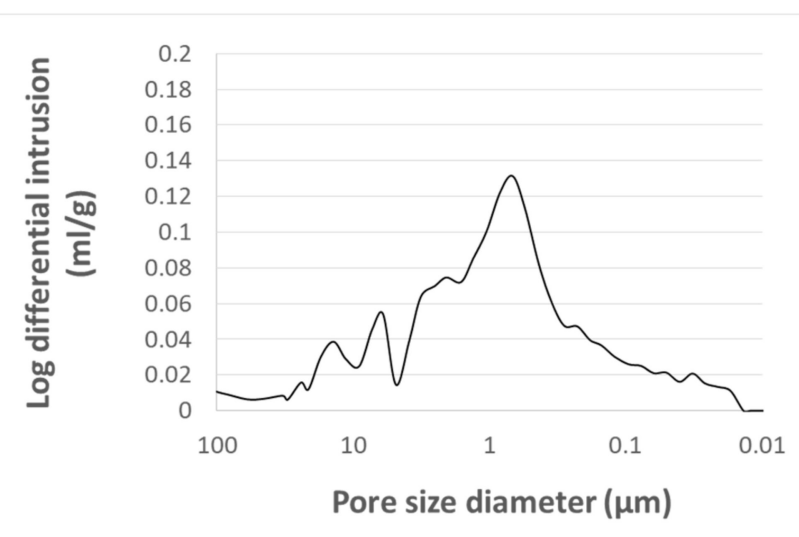

(a)

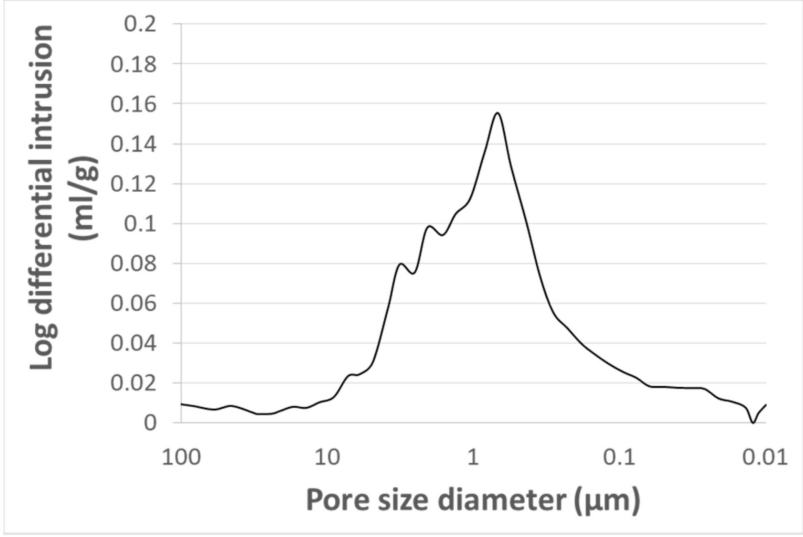

(c)

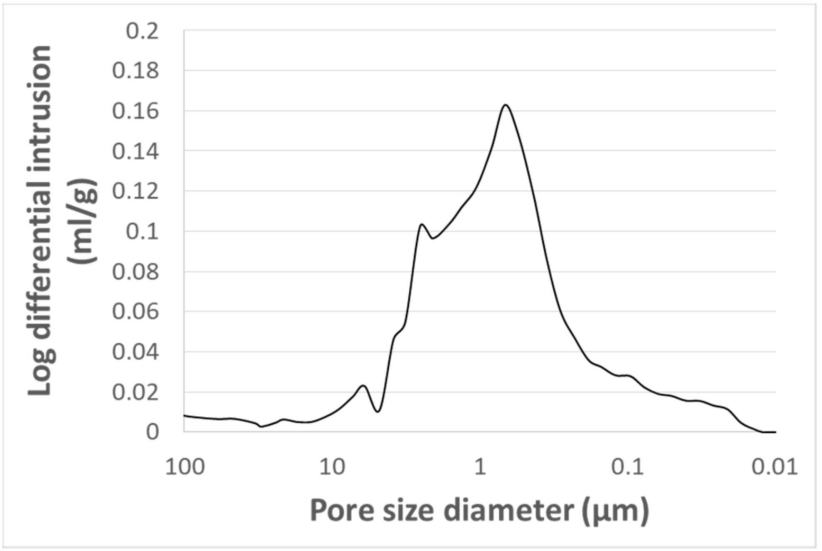

(b)

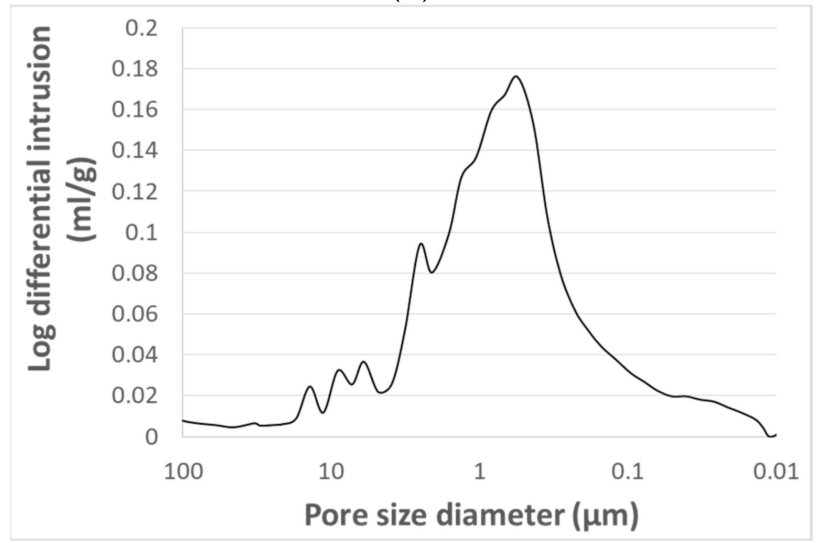

(d)

Figure 5. Pore size distributions of: (a) ETD; (b) ETDK2; (c) ETDK3; and (d) ETDK5 samples.

\subsection{BET Surface Area Analysis Results}

In Figure 6a, the Brunauer-Emmett-Teller (BET) adsorption/desorption isotherms of the reference and the three photocatalytic renders are presented. An isotherm represents the relationship between the amount of $\mathrm{N}_{2}$ adsorbed by a unit mass of material and the equilibrium pressure at known temperature following the BET equation [74]. A change in the $\mathrm{N}_{2}$ adsorption/desorption isotherms is observed for the different amounts of $\mathrm{TiO}_{2}$ 
added to the lime renders, which led to different surface areas. The specific surface area values and respective standard deviation bars are presented in Figure $6 \mathrm{~b}$. The reference sample ETD showed the lowest surface area of $1.6 \mathrm{~m}^{2} / \mathrm{g}$. In summary, the BET results (Figure 6) showed that surface area increased upon addition of the nanoparticles, i.e., an increase of $65 \%$ in the surface area was observed for the ETDK5 lime render with respect to the reference sample (ETD).

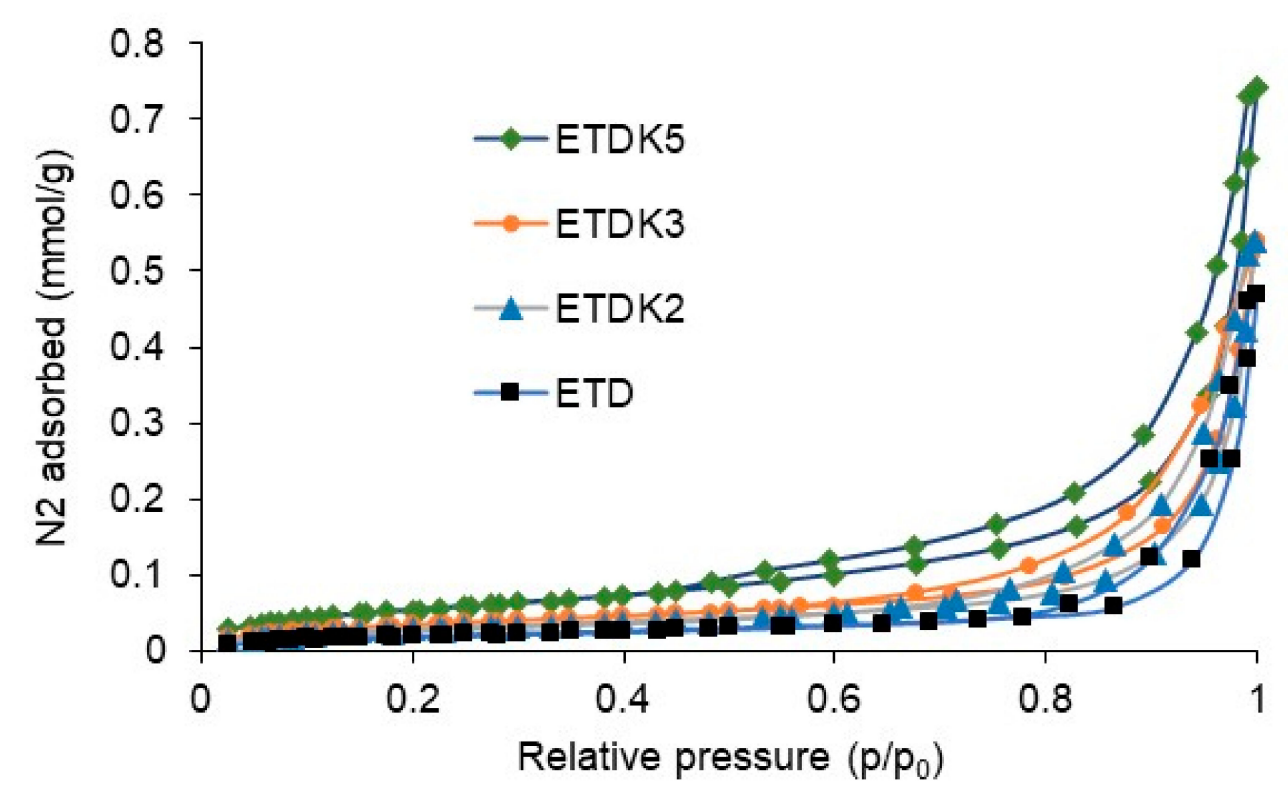

(a)

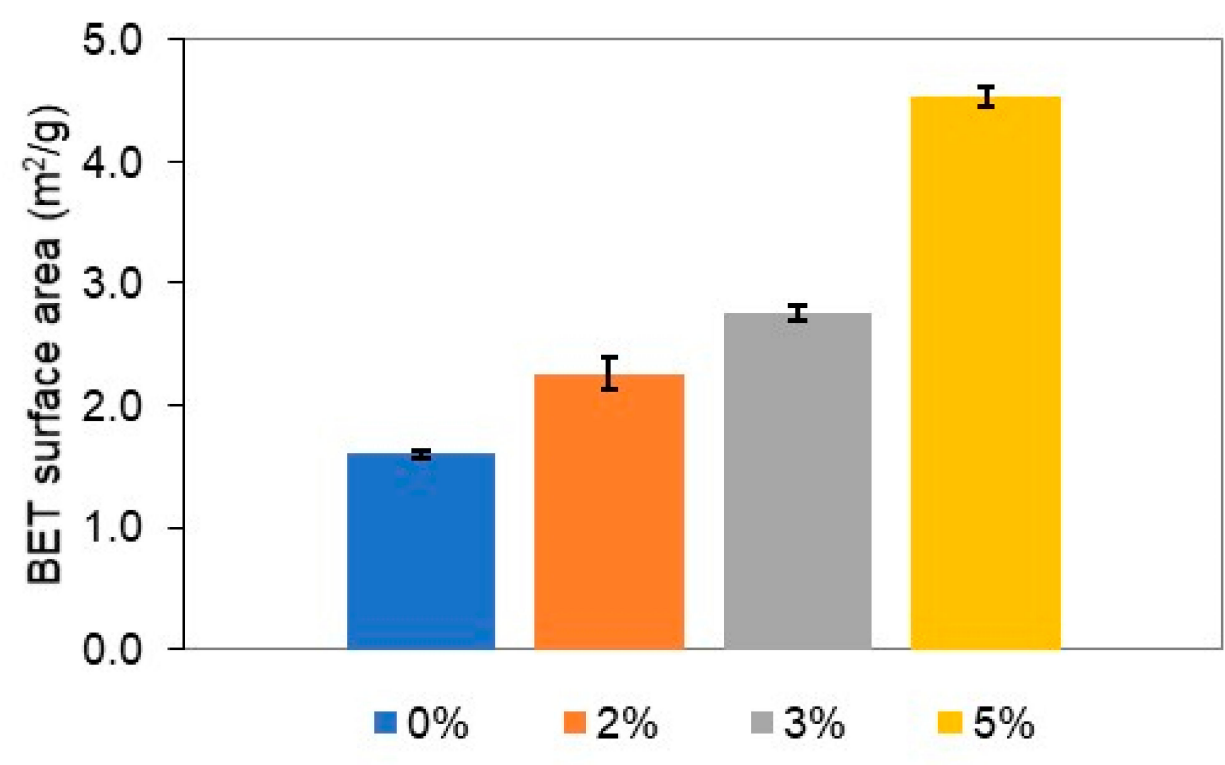

(b)

Figure 6. (a) $\mathrm{N}_{2}$ adsorption/desorption isotherms and (b) specific surface area measured by BET surface area analysis for ETD, ETDK2, ETDK3, and ETDK5 samples (Error bars indicate the variance).

\subsection{Adhesion Test Results}

Given that photocatalytic reactions take place on the surface of the materials, the most efficient and economic use of a photocatalytic mortar is as a rendering material. Hence, a 
good adhesion of the photocatalytic render to the substrate is a key feature and will ensure that the rendering layer is firmly supported.

The results of the adhesion tests are shown in Table 3. The (ETDK) photocatalytic lime renders in addition to the reference (ETD) all demonstrated good adhesion to the underlying PF80 substrate with a resistance ranging from 0.12 to $0.15 \mathrm{MPa}$. In addition, the photocatalytic renders have a superior adhesion to the substrate compared to the reference sample ETD. In fact, the adhesion tends to increase slightly (from 0.11 to $0.15 \mathrm{MPa}$ ) when the amount of K7000 increases.

Table 3. Adhesion test data for the formulated photocatalytic lime renders and the reference sample.

\begin{tabular}{|c|c|c|c|c|c|c|c|}
\hline \multirow{2}{*}{ Sample } & \multirow{2}{*}{ Test Point } & \multicolumn{3}{|c|}{ Test Surface } & \multirow{2}{*}{$\begin{array}{l}\text { Load } \\
(\mathbf{N})\end{array}$} & \multirow{2}{*}{$\begin{array}{c}\text { Resistance } \\
\text { (MPa) }\end{array}$} & \multirow{2}{*}{ Fracture Zone } \\
\hline & & $(\mathrm{mm})$ & $(\mathrm{mm})$ & $\left(\mathrm{mm}^{2}\right)$ & & & \\
\hline \multirow{4}{*}{ ETD } & 1 & 48 & 46 & 2208 & 231 & 0.10 & \multirow{4}{*}{$100 \%$ PF80 substrate } \\
\hline & 2 & 51 & 46 & 2346 & 258 & 0.11 & \\
\hline & 3 & 50 & 46 & 2300 & 270 & 0.12 & \\
\hline & 4 & 49 & 53 & 2597 & 307 & 0.12 & \\
\hline Average & & & & & 207 & 0.11 & \multirow{5}{*}{$\begin{array}{l}\text { 100\% PF80 substrate. } \\
70 \% \text { PF80 substrate- } 30 \% \\
\text { coating limit. } \\
90 \% \text { PF80 substrate-10\% } \\
\text { coating limit. } \\
\text { 80\% PF80 substrate-20\% } \\
\text { coating limit. }\end{array}$} \\
\hline \multirow{4}{*}{ ETDK2 } & 1 & 47 & 50 & 2350 & 307 & 0.13 & \\
\hline & 2 & 49 & 46 & 2254 & 248 & 0.11 & \\
\hline & 3 & 48 & 47 & 2256 & 294 & 0.13 & \\
\hline & 4 & 50 & 45 & 2250 & 269 & 0.12 & \\
\hline Average & & & & & 280 & 0.12 & \\
\hline \multirow{4}{*}{ ETDK3 } & 1 & 50 & 50 & 2500 & 307 & 0.12 & \multirow{4}{*}{$100 \%$ PF80 substrate } \\
\hline & 2 & 49 & 44 & 2156 & 301 & 0.14 & \\
\hline & 3 & 50 & 50 & 2500 & 434 & 0.17 & \\
\hline & 4 & 48 & 48 & 2304 & 454 & 0.20 & \\
\hline Average & & & & & 374 & 0.16 & \\
\hline \multirow{4}{*}{ ETDK5 } & 1 & 48 & 47 & 2256 & 348 & 0.15 & \multirow{4}{*}{$100 \%$ PF80 substrate } \\
\hline & 2 & 51 & 45 & 2295 & 343 & 0.15 & \\
\hline & 3 & 50 & 49 & 2450 & 366 & 0.15 & \\
\hline & 4 & 50 & 46 & 2300 & 308 & 0.13 & \\
\hline Average & & & & & 341 & 0.15 & \\
\hline
\end{tabular}

The fracture surface of these samples usually takes place within the substrate, which implies that the formulated photocatalytic renders adhere strongly to the PF80 substrate.

\subsection{Photocatalytic $\mathrm{NO}_{x}$ Degradation under UV Light}

The results of the photocatalytic $\mathrm{NO}_{x}$ degradation tests for ETDK2, ETDK3, and ETDK5 samples are shown in Figure 7 and Table 4. The average $\mathrm{NO}$ and $\mathrm{NO}_{\mathrm{x}}$ conversion has been calculated for every formulation according to Equations (10) and (11) in Section 3.3.1.

Table 4. Results of the photocatalytic abatement of $\mathrm{NO}_{x}$ under UV light.

\begin{tabular}{ccc}
\hline Sample & NO Reduction (\%) & NO $_{\mathbf{x}}$ Reduction (\%) \\
\hline ETD & 7.1 & 5.4 \\
ETDK2 & 7.7 & 5.4 \\
ETDK3 & 11.2 & 10.6 \\
ETDK5 & 13.1 & 12.3 \\
\hline
\end{tabular}




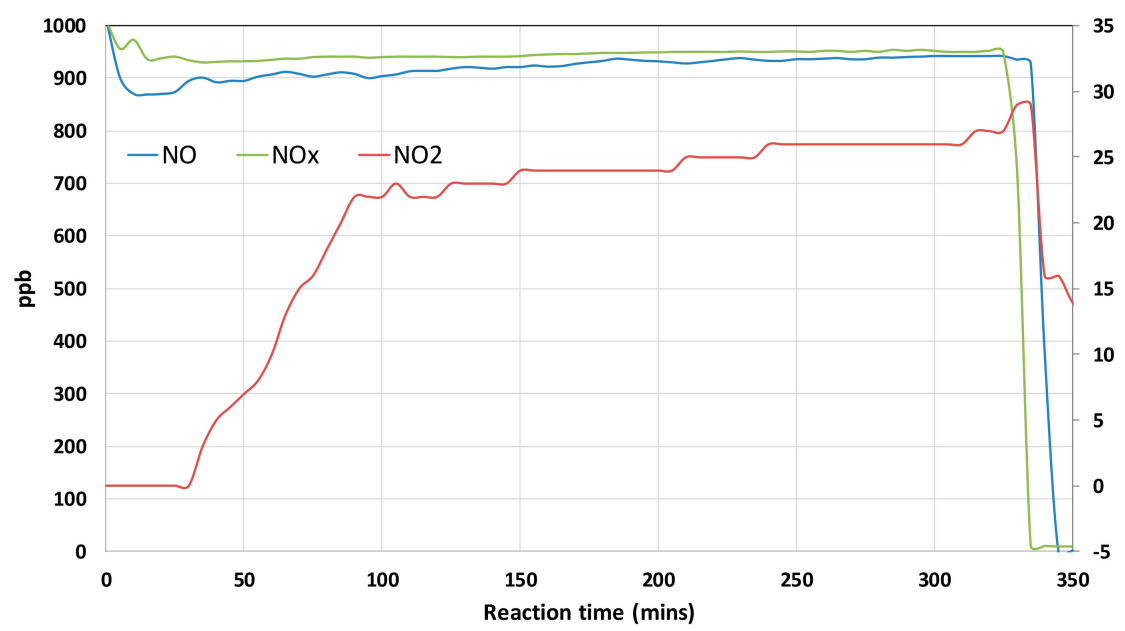

(a)

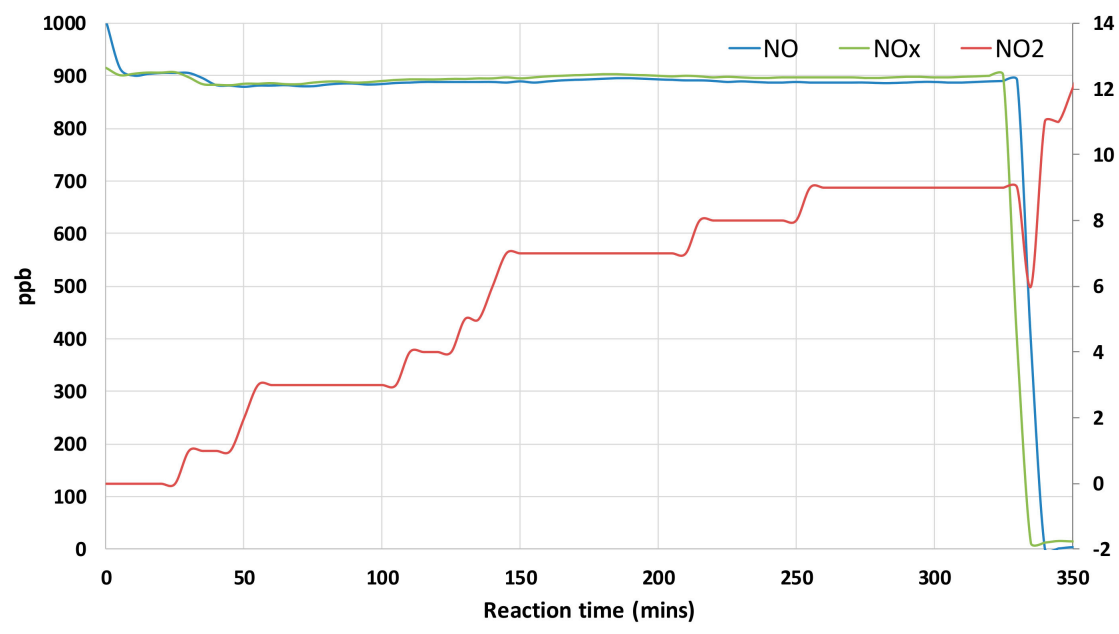

(b)

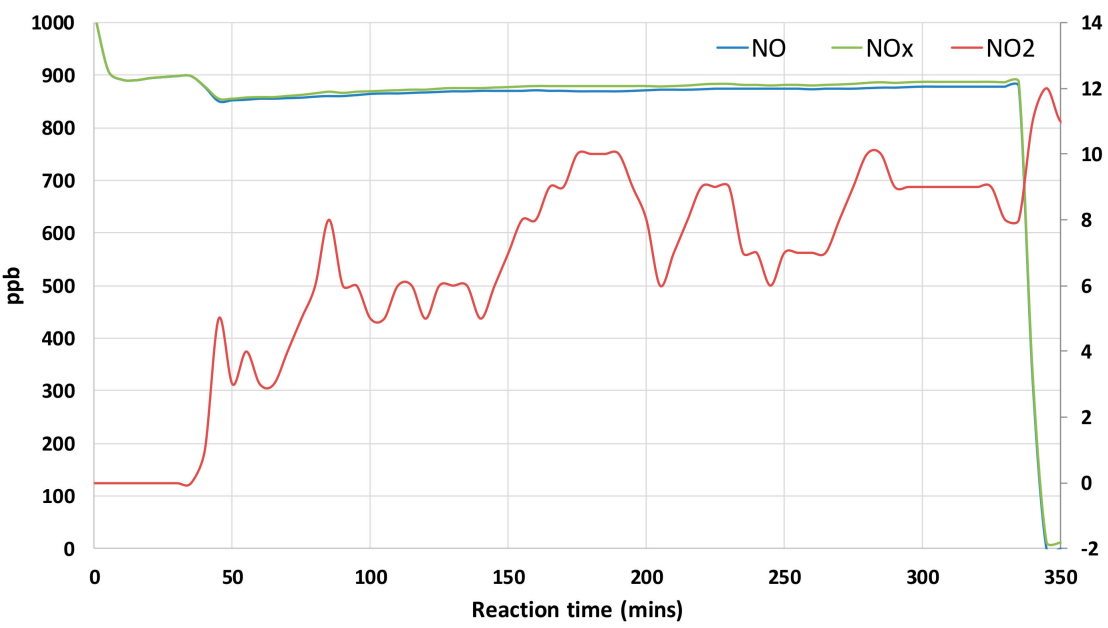

(c)

Figure 7. $\mathrm{NO}_{x}$ abatement by the (a) ETDK2, (b) ETDK3, and (c) ETDK5 samples. Left vertical axis, concentration of $\mathrm{NO}$ and $\mathrm{NO}_{x}$; right vertical axis, concentration of $\mathrm{NO}_{2}$. 
The graphics in Figure 7 show the evolution of the concentration of the $\mathrm{NO}, \mathrm{NO}_{2}$, and $\mathrm{NOx}\left(\mathrm{NO}+\mathrm{NO}_{2}\right)$ during the test. The $\mathrm{NO}$ pollutant is fed into the $\mathrm{NO}_{\mathrm{x}}$ reactor and when initially the light is off, it is adsorbed by the mortar, decreasing its concentration until it stabilizes once the pores are saturated. As soon as the UV light is turned on, the photocatalysis begins and the $\mathrm{NO}$ concentration decreases again, because it is converted to $\mathrm{NO}_{2}$, whose concentration increases continuously while light and $\mathrm{NO}$ supply is kept until the test is interrupted after six hours. The $\mathrm{NO}_{x}$ degradation test results show that a $2 \mathrm{wt} \%$ addition of K7000 did not contribute any photocatalytic performance to the lime render, the $\mathrm{NO}$ and $\mathrm{NO}_{2}$ reduction being the same as that measured in the blank ETD specimen-the measured reduction has to be ascribed to adsorption. However, increasing photocatalytic nanoparticle content from 2 to $5 \mathrm{wt} \%$ yields approximately twice the amount of $\mathrm{NO}_{\mathrm{x}}$ degradation, i.e., sample ETDK5 was shown to degrade up to $12 \% \mathrm{NO}_{\mathrm{x}}$ under UV light.

\subsection{Photocatalytic Formaldehyde Degradation under Visible Light}

In the course of this test for photocatalytic formaldehyde degradation under visible light, four different phases were studied. In Phase 1, the chamber was flushed with neutral air when the intrinsic emissions from the specimen without exposure to light could be detected. In Phase 2, the chamber was flushed with neutral air, and the lamps (visible light) were turned on, irradiating the specimen surface in order to examine the light-induced emission of formaldehyde from the samples. In Phase 3, additional gas with an airflow of $1.65 \mathrm{~L} / \mathrm{min}$ and a concentration of formaldehyde of approximately $90 \mathrm{ppb}$ equivalent to a total of $12.2 \mu \mathrm{g} / \mathrm{h}$ of formaldehyde was fed over the surface of each sample with the lamps still turned on. Thus, at this stage, the photocatalytic degradation of formaldehyde by the sample could be detected. In Phase 4, the lights were switched off, and the addition of the formaldehyde was continued. Thus, the adsorption of formaldehyde by the sample could be determined at this stage. All phases were maintained until a stable formaldehyde concentration was reached for all samples. A total of $839 \mathrm{~h}$ was required to carry out all phases of the test. The formaldehyde degradation test profile is shown in Figure 8.

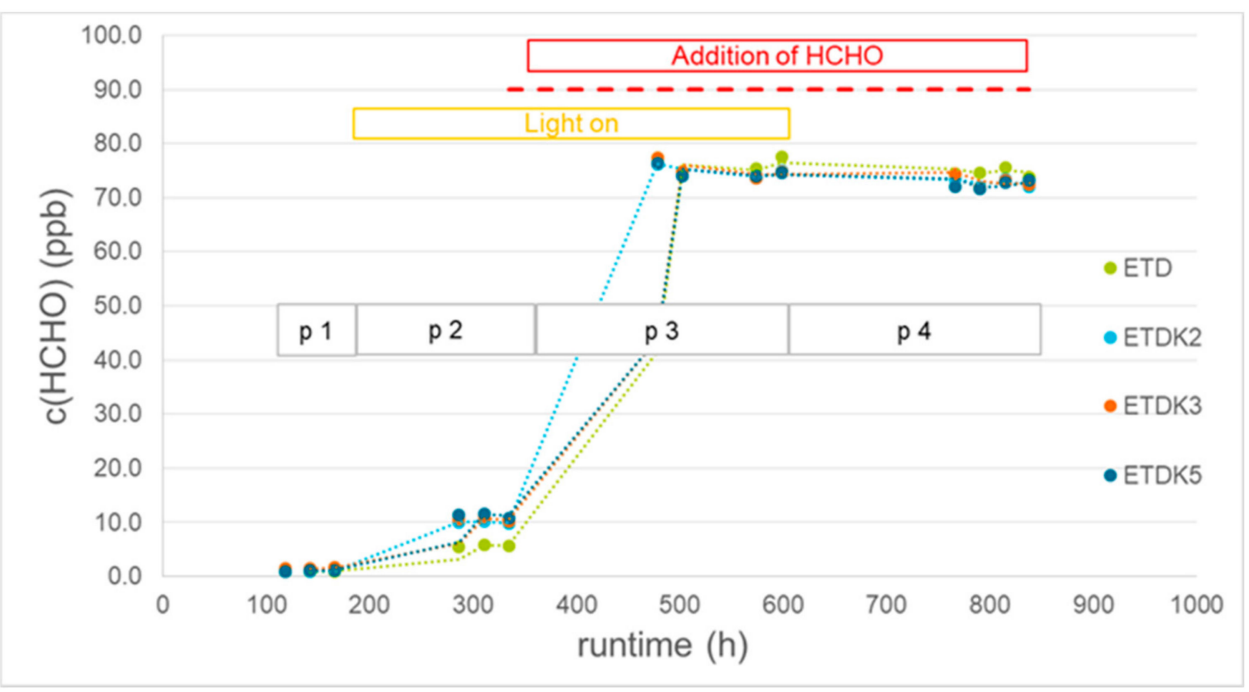

Figure 8. Photocatalytic formaldehyde degradation test profiles for all the samples. The red dashed line represents the incoming concentration of formaldehyde during phases 3 and 4.

From the equilibration formaldehyde concentrations in the different testing phases, the desired variables are defined as shown below. For every phase, the resulting formaldehyde concentration can be calculated by Equation (2):

$$
\mathrm{C}_{\text {Res }}=\mathrm{C}_{\mathrm{in}}+\mathrm{C}_{\text {ProdO }}+\mathrm{C}_{\text {ProdL }}-\mathrm{C}_{\text {RedL }}-\mathrm{C}_{\text {RedA }}
$$


where

$\mathrm{C}_{\mathrm{Res}}$ : resulting formaldehyde concentration

$C_{\text {in }}$ : formaldehyde concentration measured in the empty reference chamber

$C_{\text {Prodo }}$ : formaldehyde concentration from the self emission of the specimen

$\mathrm{C}_{\text {ProdL }}$ : formaldehyde concentration from sample emission caused by radiation

$\mathrm{C}_{\text {RedL }}$ : reduction of formaldehyde concentration caused by radiation

$\mathrm{C}_{\text {RedA }}$ : reduction of formaldehyde concentration caused by adsorption.

For the different phases of the experiment (see Figure 7), the resulting formaldehyde concentration can be calculated using the following equations:

$$
\begin{gathered}
C_{\text {Res }} \text { (phase1) }=C_{\text {ProdO }}, \\
\left.C_{\text {Res }} \text { (phase }\right)=C_{\text {ProdO }}+C_{\text {ProdL }} \\
\left.C_{\text {Res }} \text { (phase } 3\right)=C_{\text {in }}+C_{\text {ProdO }}+C_{\text {ProdL }}-C_{\text {RedL }}-C_{\text {RedA }} \\
\left.C_{\text {Res }} \text { (phase } 4\right)=C_{\text {in }}+C_{\text {ProdO }}-C_{\text {RedA }} .
\end{gathered}
$$

The specimen performance parameters are obtained from the following equations:

$$
\begin{gathered}
C_{\text {RedL }}=C_{\text {Res }}(\text { phase } 4)-C_{\text {Res }}(\text { phase } 3)+C_{\text {Res }}(\text { phase } 2)-C_{\text {Res }}(\text { phase } 1), \\
C_{\text {ProdL }}=C_{\text {Res }}(\text { phase } 2)-C_{\text {Res }}(\text { phase } 1), \\
C_{\text {RedA }}=-C_{\text {Res }}(\text { phase } 4)+C_{\text {Res }}(\text { phase } 1)+C_{\text {in }} .
\end{gathered}
$$

The equilibrium formaldehyde concentrations at the end of each experimental phase for all samples are listed in Table 5. Control experiments of the blank specimen (ETD) were also assessed; however, ETD data are not shown in Table 5, as this showed a negligible reduction in the formaldehyde initial concentration $(<5 \%)$ due to adsorption.

Table 5. Formaldehyde equilibrium concentrations.

\begin{tabular}{|c|c|c|c|c|c|c|}
\hline Sample & $\begin{array}{c}\mathrm{C}_{\text {RedL }} \\
\text { (Equation (7)) } \\
(\mathrm{ppb}) \\
\mathrm{C}_{\text {in }}=90\end{array}$ & $\begin{array}{c}\text { Reduction by } \\
\text { Photocatalysis } \\
(\%)\end{array}$ & $\begin{array}{c}\text { Standard } \\
\text { Deviation (\%) }\end{array}$ & $\begin{array}{c}\mathrm{C}_{\text {RedA }} \\
\text { (Equation (9)) } \\
(\mathrm{ppb}) \\
\mathrm{C}_{\mathrm{in}}=90\end{array}$ & $\begin{array}{c}\text { Reduction by } \\
\text { Adsorption (\%) }\end{array}$ & $\begin{array}{c}\text { Standard } \\
\text { Deviation (\%) }\end{array}$ \\
\hline ETD & 6 & 6.7 & 2.7 & 16 & 17.8 & 2.4 \\
\hline ETDK2 & 9 & 10.0 & 2.5 & 18 & 20.0 & 2.5 \\
\hline ETDK3 & 10 & 11.1 & 3.5 & 18 & 20.0 & 2.9 \\
\hline ETDK5 & 9 & 10.0 & 2.5 & 19 & 21.1 & 2.4 \\
\hline
\end{tabular}

\begin{tabular}{ccccc}
\hline Sample & $\begin{array}{c}\mathrm{C}_{\text {Res }} \text { (Phase 1) } \\
\text { Own Emission } \\
\text { without Light (ppb) }\end{array}$ & $\begin{array}{c}\mathrm{C}_{\text {Res }} \text { (Phase 2) } \\
\text { Own Emission with } \\
\text { Light (ppb) }\end{array}$ & $\begin{array}{c}\mathrm{C}_{\text {Res }} \text { (Phase 3) } \\
\text { Own Emission with } \\
\text { Light + Addition of } \\
\text { Formaldehyde (ppb) }\end{array}$ & $\begin{array}{c}\mathrm{C}_{\text {Res }} \text { (Phase 4) } \\
\text { Own Emission without } \\
\text { Light + Addition of } \\
\text { Formaldehyde (ppb) }\end{array}$ \\
\hline ETDK2 & 1 & 10 & 75 & 73 \\
ETDK3 & 1 & 11 & 75 & 73 \\
ETDK5 & 1 & 11 & 75 & 72 \\
\hline
\end{tabular}

Based on the equilibrium concentrations, the reduction rates of formaldehyde (either caused by photocatalytic reactions or by adsorption) can be calculated and are listed in Table 6 for the different samples. Equations (7) and (9) were used, and a normalization in relation with the incoming air $(90 \mathrm{ppb})$ was carried out to compare the results.

Table 6. Reduction of formaldehyde by photocatalysis and by adsorption of all samples.

The reduction of formaldehyde by photocatalysis was found to be ca. 10-11\% (Table 6) for all lime renders. This indicates that increasing the K7000 concentration from 3 to $5 \mathrm{wt} \%$ 
does not lead to an increase in photocatalytic performance. So, ETDK3 was selected as the optimum sample in terms of cost efficiency versus photocatalytic activity.

\section{Experimental}

\subsection{Materials and Sample Preparation}

The Tradical Décor lime render (supplied by BCB-Lhoist) was used to prepare the photocatalytic coating. Four specimens of these materials were prepared with different contents of carbon-modified $\mathrm{TiO}_{2}$ nanoparticles KRONOClean $7000^{\circledR}$ (K7000) with respect to the dry mixture $(0,2,3$ and $5 \mathrm{wt} \%)$. These titanium dioxide nanoparticles have a BET specific surface area $>225 \mathrm{~m}^{2} / \mathrm{g}$ and anatase as the only crystalline phase. This consisted of a small fraction of anatase domains in the size range 11.9-15.5 nm, co-existing with a much larger quantity of domains of size 3.8 to $4.4 \mathrm{~nm}$, with an amorphous phase content between 6.5 and $8.1 \mathrm{wt} \%$. An aromatic carbon compound (likely aryl carboxylate species) is at the origin of the visible-light absorption as previously characterized by the authors of this manuscript [40].

For the photocatalytic render preparation, all the dry components were first mixed for approximately $3 \mathrm{~min}$ (using an automatic mixer), without any previous treatment; then, water was added in two steps, as described in the Tradical Décor technical data sheet [75]. Then, the resulting mixture was further mixed in an automatic mixer, which meets the European Norm: EN 196-1 [76]. Then, the fresh render was poured into molds ( $210 \mathrm{~mm} \times 297 \mathrm{~mm}$ in size). The render thickness could range from 2 to $20 \mathrm{~mm}$. For the photocatalytic characterization, the renders were prepared as $20 \mathrm{~mm}$ thick samples. Whereas for the adhesion measurements, the renders were prepared as $3 \mathrm{~mm}$ thick samples by manual application (i.e., spatula) onto a PF80 lime substrate. This substrate was made cutting fiber boards to normalized A4-size that were inserted in wood frames where later Tradical PF80 mortar (provided by BCB -Lhoist) was added as a $30 \mathrm{~mm}$ layer on the framed fiber boards and later cured for 28 days.

All the samples prepared were cured for at least 28 days in an environmental chamber at $22{ }^{\circ} \mathrm{C}\left( \pm 2{ }^{\circ} \mathrm{C}\right)$, humidity of $53 \%( \pm 3 \%)$ before any testing and characterization were carried out.

The samples obtained are referred to as ETD, ETDK2, ETDK3, and EDTK5 corresponding to the percentage of K7000 incorporated into the lime render (0, 2, 3 and $5 \mathrm{wt} \%$ respectively). The water/lime render ratios employed in their preparation were as follows: ETD and ETDK2: 0.22, ETDK3: 0.24, ETDK5: 0.26.

All these samples were characterized in terms of their physical properties and of their photocatalytic activity in the degradation of $\mathrm{NO}_{\mathrm{x}}$ under UV light and of formaldehyde under visible light.

\subsection{Characterization}

Color variation of the photocatalytic samples was measured using a Color Eye XTH from Gretag Macbeth spectrophotometer with a D65-10 light source and compared to the blank sample. Three points at different locations on the surface of each sample were analyzed. XRD patterns and mineralogical information were obtained using a Philips X'Pert Pro MPD PW3040/60 X-ray diffractometer equipped with a copper anode operating with a voltage of $40 \mathrm{kV}$ and $40 \mathrm{~mA}(1.6 \mathrm{~kW})$. The scans were performed in a $2 \theta$ range from $2^{\circ}$ to $75^{\circ}$ with a step size of $0.02^{\circ} 2 \theta$. Representative chips of the surface of each sample were taken with a mass of approximately $2 \mathrm{~g}$, ground with an automatic micro mill, and analyzed by X-ray powder diffraction. Scanning electron microscopy (SEM) images with correlated energy-dispersive X-ray (EDX) spectra were acquired using a FEI Quanta 200 ESEM with a Genesis 4000 system X-ray energy dispersive fluorescence spectrophotometer. Both the SEM images and the EDX spectra were acquired using uncoated samples at a sample chamber pressure of $60 \mathrm{~Pa}$, accelerating voltage of $25 \mathrm{keV}$, and a working distance of $11 \mathrm{~mm}$. For this study, representative flat fragments (size $20 \times 20 \mathrm{~mm}$ ) were taken from the surface of each sample. 
Porosity, skeletal density, bulk density, and average pore size were measured by a Mercury Intrusion Porosimetry (MIP) using a Micromeritics Autopore IV 9500 model with a mercury-filling pressure range between 0.0036 and $228 \mathrm{MPa}$ with an equilibration time of $10 \mathrm{~s}$. For this work, representative fragments, each with a mass of approximately $2 \mathrm{~g}$, were taken from the surface of each sample. This technique uses a glass bulb where the sample resides, and that is filled with mercury at increasing pressures while the volume of the mercury is monitored, yielding a mercury intrusion curve that correlates intruded mercury at different pressures and serves for calculating the different measurements by the software of the equipment (Autopore IV v1.09).

To measure the surface area, the amount of adsorbed $\mathrm{N}_{2}$ required to cover the material surface is determined. The amount of gas adsorbed by the mass of material being tested is dependent on the relative pressure and temperature isotherm. The nitrogen BET surface area of the renders was measured using a Micrometrics 3Flex surface characterization analyzer following BS ISO 9277:2010 [77]. In total, $0.7 \mathrm{~g}$ was used for each sample. Prior to the surface area measurements, all samples were degassed to remove any water or other volatile molecules physically adsorbed on the surface. The degas phase was carried out in situ at $10{ }^{\circ} \mathrm{C} / \mathrm{min}$ until $105{ }^{\circ} \mathrm{C}$ was reached after $120 \mathrm{~min}$. Following the degassing phase, the adsorption and desorption cycle of nitrogen began. Then, the nitrogen BET surface area values were calculated using the 3Flex software version 3.02. Three samples of each specimen were analyzed for statistical purposes. The adhesion of the four lime renders to the Tradical PF 80 mortar substrate was measured. The layer of the lime render had a thickness of $3 \mathrm{~mm}$. The adhesion tests were performed according to the norm EN 1015-12:2000 [78].

\subsection{Evaluation of Photocatalytic Activity}

\subsection{1. $\mathrm{NO}_{\mathrm{x}}$ Degradation Test}

The test set-up used for the photocatalytic oxidation experiment for $\mathrm{NO}_{\mathrm{x}}$ was according to the ISO Standard 22197-1: 2007 [79], which describes a test method for determining the air-purification performance of semiconducting photocatalytic materials. The experimental set-up is composed of the reactor, light source, target gas pollutant (NO) supply, transport gas (free pollutant air) supply, $\mathrm{NO}_{\mathrm{x}}$ analyzer (CM2041 from Casella Monitors), flow meters, relative humidity control, and parameter measurement apparatus such as temperature and relative humidity.

The experimental procedure followed to carry out the $\mathrm{NO}_{\mathrm{x}}$ degradation tests is also based on the test procedure described in ISO 22197-1, which concerns the development, comparison, quality assurance, characterization, reliability, and design data generation of photocatalytic materials. The method described is intended to assess the air-purification performance of photocatalytic materials by exposing a test piece to model polluted air under illumination by ultraviolet (UV) light. The supply gas flow rate (free pollutant air $+\mathrm{NO}$ ) for these tests was $3 \mathrm{~L} / \mathrm{min}$, and the NO gas concentration was $1000 \mathrm{ppb}$. Nitric oxide $(\mathrm{NO})$ is chosen as a target pollutant. The test piece, placed in a flow-type photoreactor, is activated by UV light, and it adsorbs and oxidizes gas-phase NO to form nitric acid (or nitrate) on its surface. A part of the $\mathrm{NO}$ is converted to nitrogen dioxide $\left(\mathrm{NO}_{2}\right)$ on the test piece.

Since the degradation of nitrogen oxides by photocatalysis leads to the oxidation of $\mathrm{NO}$ to $\mathrm{NO}_{2}$ in the first reaction stage, the photocatalytic performance of these lime renders was assessed by two degradation rates calculated as follows (Equations (10) and (11)):

$$
\begin{gathered}
N O, \operatorname{conv}(\%)=\frac{N O_{\text {in }}-N O_{\text {out }}}{N O_{\text {in }}} * 100, \\
N O_{x}, \operatorname{conv}(\%)=\frac{N O_{\text {xin }}-N O_{\text {xout }}}{N O_{\text {xin }}} * 100,
\end{gathered}
$$

where $\mathrm{NO}_{x}=\mathrm{NO}+\mathrm{NO}_{2}$.

The samples tested were ETDK2, ETDK3, and ETDK5. 


\subsubsection{Formaldehyde Degradation Test}

A custom-made experimental set-up based on the ISO/18560-1 [80] was developed for the evaluation of photocatalytic formaldehyde degradation performance. Samples were placed in $28.2 \mathrm{~L}$ test chambers sealed on the top by a special type of borosilicate glass with a 100\% transmission down to $350 \mathrm{~nm}$. Adjustable slot floors in the test chamber allowed the surface of each individual sample to be located at a distance of $5 \mathrm{~mm}$ below the glass panel regardless of the sample thickness. The fluorescent tubes were placed on top of the glass windows so that the entire specimen surface was irradiated homogeneously. The air flow was fed through the gap between the glass panel and the surface of the sample in the test chamber, following which the exhaust was divided into two streams, allowing both on-line and off-line analysis. The air supplied into the test chamber was humidified and enriched with formaldehyde as required by blending humidified neutral air with the test gas. Gases were homogeneously mixed before entering the test chambers, as shown in Figure 9. The whole system included a total of six test chambers for parallel operation. A flow meter was connected in line with the gas supply to each chamber and adjusted in order to ensure that an equal flux of test gas was delivered to all six test chambers, as seen in Figure 10.

Neutral air that did not contain any formaldehyde or VOCs was provided by the institute's compressed air system and guided through several cleaning steps to guarantee purity and ultimately through a humidification unit in which a dew point of $12.5^{\circ} \mathrm{C}$ was set. This corresponds to a relative humidity of $50 \%$ at $23{ }^{\circ} \mathrm{C}$. The test gas was enriched through the addition of calibration gases that contained approximately $15 \mathrm{ppm}$ of formaldehyde in nitrogen. That calibration gas was diluted by cleaned neutral air to produce a test gas with a formaldehyde concentration of $90 \mathrm{ppb}$. The flow of both neutral air and the enriched test gas was regulated by mass flow controllers with a resulting flow through each chamber of $1.6 \mathrm{~L} / \mathrm{min}$. Tests were conducted under irradiation from Osram Lumilux warm white $36 \mathrm{~W}$ tubular fluorescent lamps of $26 \mathrm{~mm}$ diameter mounted to G13 bases, which ensured the entire irradiated area was illuminated evenly. This type of lamp is one commonly used for indoor lighting in offices and elsewhere.

The concentration of formaldehyde was measured using an AL4021 analyzer manufactured by Aero-Laser GmbH (Gesellschaft für Gasanalytik, Unterfeldstraße 12, D-82467 Garmisch-Partenkirchen, Germany). Fluorescent emission after the reaction of formaldehyde with acetylacetone and ammonia was measured in a linear detection range between 0.1 and $3000 \mathrm{ppb}$ with a detection limit of $0.1 \mathrm{ppb}$. The analyzer was calibrated beforehand for a measurement range between 0.1 and $400 \mathrm{ppb}$.

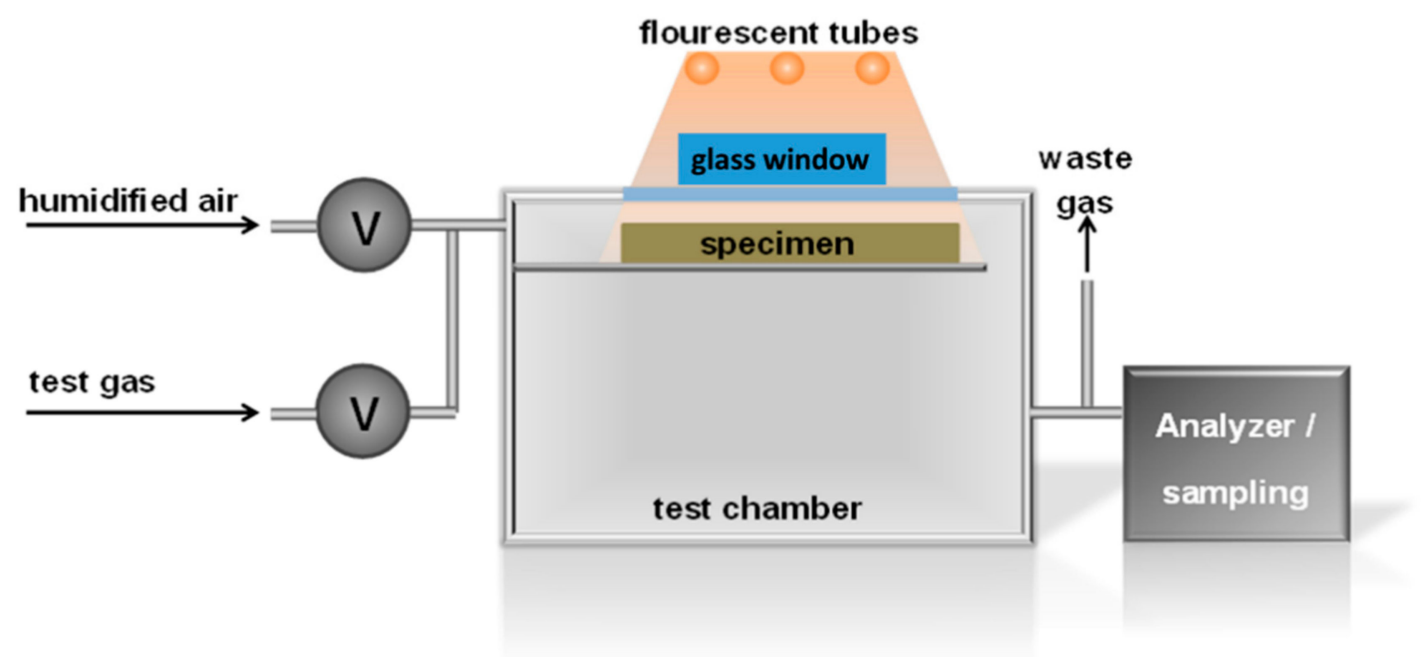

Figure 9. Schematic photocatalytic formaldehyde degradation test chamber assembly. 


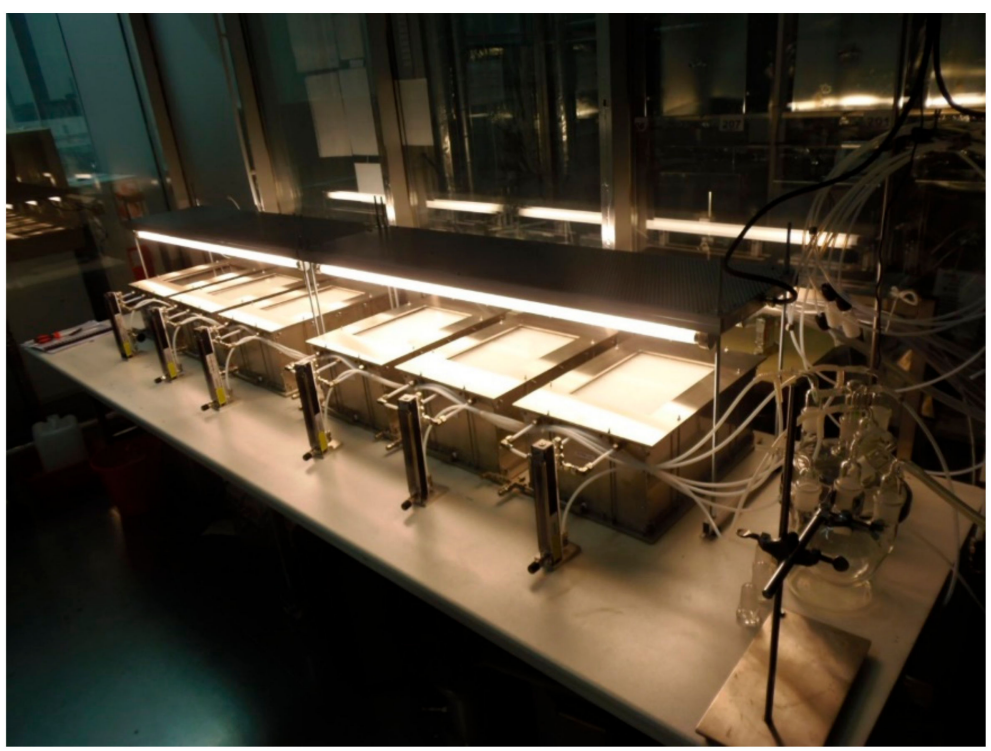

Figure 10. Formaldehyde degradation test: assembly of the six test chambers in the glass cabin.

\section{Conclusions}

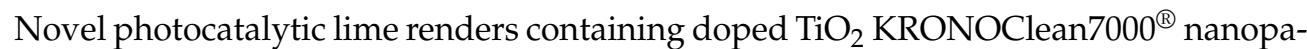
rticles have been successfully prepared and fully characterized. Their photocatalytic activity, in the degradation of $\mathrm{NO}_{\mathrm{x}}$ under UV light and of formaldehyde under visible light, has been studied; therefore, their suitability for air quality improvement both in outdoor and indoor environments has been examined.

No detrimental changes in physical properties (e.g., color) were observed upon the addition of 2, 3 and $5 \mathrm{wt} \%$ of these nanoparticles to the lime render. The results of mineralogical and EDX analysis showed few significant changes between the traditional and photocatalytic lime renders due to the presence of the anatase $\mathrm{TiO}_{2}$ nanoparticles. In addition, the porosimetry studies only showed a small increase in porosity in the case of sample ETDK5 (5 wt \%) with respect to the reference sample (ETD), i.e., porosity increased from $29 \%$ for ETD to $33 \%$ for ETDK5. The BET results showed that the surface area increases upon the addition of nanoparticles to the lime render, e.g., an increase of $65 \%$ in the surface area was observed for the ETDK5 lime render with respect to the reference sample (ETD). More importantly, it was also demonstrated that the presence of the K7000 nanoparticles within the chosen lime render does not negatively affect its adhesion to the lime mortar (PF80) substrate. Finally, these novel materials were shown to degrade up to $12 \% \mathrm{NO}_{\mathrm{x}}$ under UV light and $11 \%$ formaldehyde (VOC) under visible light.

In conclusion, this study has demonstrated that these novel photocatalytic lime renders are a technically viable solution for air quality improvement, both in the outdoor and indoor environments, under UV light and under conventional indoor lighting conditions, respectively.

Author Contributions: Conceptualization, J.A.I.G., A.G., F.M., J.A.L., Y.R.d.M. and R.J.B.; Data curation, D.M.T., F.M. and Y.R.d.M.; Formal analysis, J.A.I.G., A.G., D.M.T., F.M. and R.J.B.; Funding acquisition, F.M., J.A.L., Y.R.d.M. and R.J.B.; Investigation, A.G., S.M., M.C.B., F.M., J.A.L. and Y.R.d.M.; Methodology, J.A.I.G., D.M.T., M.C.B., F.M., J.A.L., Y.R.d.M. and R.J.B.; Project administration, F.M., J.A.L., Y.R.d.M. and R.J.B.; Resources, F.M., J.A.L. and Y.R.d.M.; Supervision, F.M. and J.A.L.; Writing-original draft, A.G., D.M.T., M.C.B., D.M., M.P.A., F.M., J.A.L., Y.R.d.M. and R.J.B.; Writing-review \& editing, C.F.d.S., M.P.A., R.K., F.M., J.A.L., Y.R.d.M. and R.J.B. All authors have read and agreed to the published version of the manuscript. 
Funding: This research was funded by the European Union's Seventh Framework Programme for research, technological development, and demonstration under the Grant Agreement No. 609234 related to the ECO-SEE project: "Eco-innovative, Safe and Energy Efficient wall panels and materials for a healthier indoor environment" (http://www.eco-see.eu/). This work was partly developed within the scope of the project CICECO-Aveiro Institute of Materials, UIDB/50011/2020 \& UIDP/50011/2020, financed by national funds through the FCT/MEC and when appropriate co-financed by FEDER under the PT2020 Partnership Agreement. David Maria Tobaldi is overly grateful to Portuguese national funds (OE), through FCT, I.P., in the scope of the framework contract foreseen in the numbers 4, 5 and 6 of the article 23, of the Decree-Law 57/2016, of 29 August, changed by Law 57/2017, of 19 July.

Acknowledgments: The authors wish to thank José Germán Fernández-Rodrigo (at Tecnalia) for his technical support with the $\mathrm{NO}_{x}$ measurements and Ulrike Peter (at BCB-Lhoist) for supplying the Tradical Decor and PF80 materials and their technical data sheets.

Conflicts of Interest: The authors declare no conflict of interest.

\section{References}

1. EC. Directive 2010/31/EU of the European Parliament and of the Council of 19 May, 2010 on the energy performance of buildings. Off. J. Eur. Union 2010, 153, 13-35.

2. Nazaroff, W.W. Exploring the consequences of climate change for indoor air quality. Environ. Res. Lett. 2013, 8, 015022. [CrossRef]

3. Yu, C.W.F.; Kim, J.T. Low-carbon housings and indoor air quality. Indoor Built Environ. 2012, 21, 5-15. [CrossRef]

4. Ball, R.J.; Pesce, G.L.; Bowen, A.C.R.; Allen, G.C. Characterisation of lime/metakaolin paste using Impedance Spectroscopy. In Key Engineering Materials; Trans Tech Publications Ltd.: Bäch, Switzerland, 2012; Volume 517, pp. 487-494. [CrossRef]

5. Ansell, M.P.; Ball, R.J.; Lawrence, M.; Maskell, D.; Shea, A.; Walker, P. Green composites for the built environment. In Green Composites; Woodhead Publishing: Cambridge, UK, 2017; pp. 123-148.

6. Sundell, J.; Levin, H.; Nazaroff, W.W.; Cain, W.S.; Fisk, W.J.; Grimsrud, D.M.T.; Gyntelberg, F.; Li, Y.; Persily, A.K.; Pickering, A.C.; et al. Ventilation rates and health: Multidisciplinary review of the scientific literature. Indoor Air 2011, 21, 191-204. [CrossRef]

7. Crump, D.R.; Squire, R.W.; Yu, C.W.F. Sources and concentrations of formaldehyde and other volatile organic compounds in the indoor air of four newly built unoccupied test houses. Indoor Built Environ. 1997, 6, 45-55. [CrossRef]

8. Kolarik, B.; Gunnarsen, L.; Logadottir, A.; Funch, L.W. Concentrations of formaldehyde in new Danish residential buildings in relation to WHO recommendations and CEN requirements. Indoor Built Environ. 2012, 21, 552-561. [CrossRef]

9. Da Silva, C.F.; Stefanowski, B.; Maskell, D.; Ormondroyd, G.A.; Ansell, M.P.; Dengel, A.C.; Ball, R.J. Improvement of indoor air quality by MDF panels containing walnut shells. Build. Environ. 2017, 123, 427-436. [CrossRef]

10. Albadra, D.; Kuchai, N.; Acevedo-De-los-Ríos, A.; Rondinel-Oviedo, D.; Coley, D.; da Silva, C.F.; Rana, C.; Mower, K.; Dengel, A.; Maskell, D.; et al. Measurement and analysis of air quality in temporary shelters on three continents. Build. Environ. 2020, 185, 107259. [CrossRef]

11. Burge, P.S. Sick building syndrome. Occup. Environ. Med. 2004, 61, 185-190. [CrossRef]

12. Uddin, M.K.; Rahaman, P.F. A study on the potential applications of rice husk derivatives as useful adsorptive material. Inorg. Pollut. Wastewater Methods Anal. Remov. Treat. 2017, 16, 149-186.

13. Carneiro, J.F.; Trevelin, L.C.; Lima, A.S.; Meloni, G.N.; Bertotti, M.; Hammer, P.; Bertazzoli, R.; Lanza, M.R. Synthesis and characterization of $\mathrm{ZrO}_{2} / \mathrm{C}$ as electrocatalyst for oxygen reduction to $\mathrm{H}_{2} \mathrm{O}_{2}$. Electrocatalysis 2017, 8, 189-195. [CrossRef]

14. Liu, G.; Xiao, M.; Zhang, X.; Gal, C.; Chen, X.; Liu, L.; Pan, S.; Wu, J.; Tang, L.; Clements-Croome, D. A review of air filtration technologies for sustainable and healthy building ventilation. Sustain. Cities Soc. 2017, 32, 375-396. [CrossRef]

15. Ren, H.; Koshy, P.; Chen, W.F.; Qi, S.; Sorrell, C.C. Photocatalytic materials and technologies for air purification. J. Hazard. Mater. 2017, 325, 340-366. [CrossRef]

16. Da Silva, C.F.F.P.; Rana, C.; Maskell, D.; Dengel, A.; Ansell, M.P.; Ball, R.J. Influence of eco-materials on indoor air quality. Green Mater. 2016, 4, 72-80. [CrossRef]

17. Nuño, M.; Pesce, G.L.; Bowen, C.R.; Xenophontos, P.; Ball, R.J. Environmental performance of nano-structured $\mathrm{Ca}(\mathrm{OH})_{2} / \mathrm{TiO}_{2}$ photocatalytic coatings for buildings. Build. Environ. 2015, 92, 734-742. [CrossRef]

18. Nuño, M.; Ball, R.J.; Bowen, C.R. Study of solid/gas phase photocatalytic reactions by electron ionization mass spectrometry. J. Mass Spectrom. 2014, 49, 716-726. [CrossRef] [PubMed]

19. Nuño, M.; Ball, R.J.; Bowen, C.R.; Kurchania, R.; Sharma, G.D. Photocatalytic activity of electrophoretically deposited (EPD) $\mathrm{TiO}_{2}$ coatings. J. Mater. Sci. 2015, 50, 4822-4835. [CrossRef]

20. Nuño, M.; Ball, R.J.; Bowen, C.R. Photocatalytic properties of commercially available $\mathrm{TiO}_{2}$ powders for pollution control. In Semiconductor Photocatalysis-Materials, Mechanisms and Applications; IntechOpen: London, UK, 2016.

21. Anpo, M.; Yamashita, H.; Ichihashi, Y.; Fujii, Y.; Honda, M. Photocatalytic reduction of $\mathrm{CO}_{2}$ with $\mathrm{H}_{2} \mathrm{O}$ on titanium oxides anchored within micropores of zeolites: Effects of the structure of the active sites and the addition of Pt. J. Phys. Chem. B 1997, 101, 2632-2636. [CrossRef]

22. Fujishima, A.; Honda, K. Electrochemical photolysis of water at a semiconductor electrode. Nature 1972, 238, 37-38. [CrossRef] 
23. Ao, C.H.; Lee, S.C. Indoor air purification by photocatalyst $\mathrm{TiO}_{2}$ immobilized on an activated carbon filter installed in an air cleaner. Chem. Eng. Sci. 2005, 60, 103-109. [CrossRef]

24. Paz, Y.; Luo, Z.; Rabenberg, L.; Heller, A. Photooxidative self-cleaning transparent titanium dioxide films on glass. J. Mater. Res. 1995, 10, 2842-2848. [CrossRef]

25. Paz, Y. Application of $\mathrm{TiO}_{2}$ photocatalysis for air treatment: Patents' overview. Appl. Catal. B Environ. 2010, 99, 448-460. [CrossRef]

26. Zhong, L.; Brancho, J.J.; Batterman, S.; Bartlett, B.M.; Godwin, C. Experimental and modeling study of visible light responsive photocatalytic oxidation (PCO) materials for toluene degradation. Appl. Catal. B Environ. 2017, 216, 122-132. [CrossRef]

27. Zhong, L.; Haghighat, F. Photocatalytic air cleaners and materials technologies-Abilities and limitations. Build. Environ. 2015, 91, 191-203. [CrossRef]

28. Almquist, C.B.; Biswas, P. Role of synthesis method and particle size of nanostructured $\mathrm{TiO}_{2}$ on its photoactivity. J. Catal. 2002, 212, 145-156. [CrossRef]

29. Kumar, S.G.; Devi, L.G. Review on modified $\mathrm{TiO}_{2}$ photocatalysis under UV/visible light: Selected results and related mechanisms on interfacial charge carrier transfer dynamics. J. Phys. Chem. A 2011, 115, 13211-13241. [CrossRef] [PubMed]

30. Şen, Z. Solar Energy Fundamentals and Modeling Techniques: Atmosphere, Environment, Climate Change and Renewable Energy; Springer: Berlin/Heidelberg, Germany, 2008.

31. Cheng, X.; Yu, X.; Xing, Z.; Wan, J. Enhanced photocatalytic activity of nitrogen doped $\mathrm{TiO}_{2}$ anatase nano-particle under simulated sunlight irradiation. Energy Procedia 2012, 16, 598-605. [CrossRef]

32. Giampiccolo, A.; Tobaldi, D.M.; Leonardi, S.G.; Murdoch, B.J.; Seabra, M.P.; Ansell, M.P.; Neri, G.; Ball, R.J. Sol gel graphene/TiO 2 nanoparticles for the photocatalytic-assisted sensing and abatement of $\mathrm{NO}_{2}$. Appl. Catal. B Environ. 2019, 243, 183-194. [CrossRef]

33. Nuño, M.; Adamaki, V.; Tobaldi, D.M.; Hortigüela Gallo, M.J.; Otero-Irurueta, G.; Bowen, C.R.; Ball, R.J. Solid-gas phase photo-catalytic behaviour of rutile and TiO n $(1<\mathrm{n}<2)$ sub-oxide phases for self-cleaning applications. Materials 2019, 12, 170.

34. Herrmann, J.M. Detrimental cationic doping of titania in photocatalysis: Why chromium $\mathrm{Cr}^{3+}$-doping is a catastrophe for photocatalysis, both under UV-and visible irradiations. New J. Chem. 2012, 36, 883-890. [CrossRef]

35. Subramanian, V.; Wolf, E.E.; Kamat, P.V. Catalysis with $\mathrm{TiO}_{2}$ /gold nanocomposites. Effect of metal particle size on the Fermi level equilibration. J. Am. Chem. Soc. 2004, 126, 4943-4950. [CrossRef] [PubMed]

36. Tobaldi, D.M.; Hortigüela Gallo, M.J.; Otero-Irurueta, G.; Singh, M.K.; Pullar, R.C.; Seabra, M.P.; Labrincha, J.A. Purely visiblelight-induced photochromism in $\mathrm{Ag}-\mathrm{TiO}_{2}$ nanoheterostructures. Langmuir 2017, 33, 4890-4902. [CrossRef]

37. Asahi, R.; Morikawa, T.; Irie, H.; Ohwaki, T. Nitrogen-doped titanium dioxide as visible-light-sensitive photocatalyst: Designs, developments, and prospects. Chem. Rev. 2014, 114, 9824-9852. [CrossRef] [PubMed]

38. Hutter, E.; Fendler, J.H.; Roy, D. Surface plasmon resonance studies of gold and silver nanoparticles linked to gold and silver substrates by 2-aminoethanethiol and 1, 6-hexanedithiol. J. Phys. Chem. B 2001, 105, 11159-11168. [CrossRef]

39. Long, R.; English, N.J. New Insights into the Band-Gap Narrowing of (N, P)-Codoped $\mathrm{TiO}_{2}$ from Hybrid Density Functional Theory Calculations. ChemPhysChem 2011, 12, 2604-2608. [CrossRef] [PubMed]

40. Tobaldi, D.M.; Seabra, M.P.; Otero-Irurueta, G.; De Miguel, Y.R.; Ball, R.J.; Singh, M.K.; Pullar, R.C.; Labrincha, J.A. Quantitative XRD characterisation and gas-phase photocatalytic activity testing for visible-light (indoor applications) of KRONOClean 7000@. RSC Adv. 2015, 5, 102911-102918. [CrossRef]

41. Giampiccolo, A.; Ball, R.; Ansell, M.; Maskell, D. Synthesis of Co-doped $\mathrm{TiO}_{2}$ nanostructures for novel photo-catalytic coatings. In Proceedings of the Energy forum on Advanced Building Skins, Bressanone, Italy, 28-29 October 2014; Available online: https: //researchportal.bath.ac.uk/en/publications/synthesis-of-co-doped-tio2-nanostructures-for-novel-photo-catalyt (accessed on 22 December 2020).

42. Giampiccolo, A.; Ansell, M.P.; Tobaldi, D.M.; Ball, R.J. Synthesis of Co-TiO 2 nanostructured photocatalytic coatings for MDF substrates. Green Mater. 2016, 4, 140-149. [CrossRef]

43. Reddy, P.A.K.; Reddy, P.V.L.; Kwon, E.; Kim, K.H.; Akter, T.; Kalagara, S. Recent advances in photocatalytic treatment of pollutants in aqueous media. Environ. Int. 2016, 91, 94-103. [CrossRef] [PubMed]

44. Jafari, H.; Afshar, S.; Zabihi, O.; Naebe, M. Enhanced photocatalytic activities of $\mathrm{TiO}_{2}-\mathrm{SiO}_{2}$ nanohybrids immobilized on cement-based materials for dye degradation. Res. Chem. Intermed. 2016, 42, 2963-2978. [CrossRef]

45. Calia, A.; Lettieri, M.; Masieri, M. Durability assessment of nanostructured $\mathrm{TiO}_{2}$ coatings applied on limestones to enhance building surface with self-cleaning ability. Build. Environ. 2016, 110, 1-10. [CrossRef]

46. Tobaldi, D.M.; Tucci, A.; Camera-Roda, G.; Baldi, G.; Esposito, L. Photocatalytic activity for exposed building materials. J. Eur. Ceram. Soc. 2008, 28, 2645-2652. [CrossRef]

47. Bergamonti, L.; Bondioli, F.; Alfieri, I.; Lorenzi, A.; Mattarozzi, M.; Predieri, G.; Lottici, P.P. Photocatalytic self-cleaning TiO 2 coatings on carbonatic stones. Appl. Phys. A 2016, 122, 124. [CrossRef]

48. Zhao, J.; Yang, X. Photocatalytic oxidation for indoor air purification: A literature review. Build. Environ. 2003, 38, 645-654. [CrossRef]

49. Kamaruddin, S.; Stephan, D. Sol-gel Mediated Coating and Characterization of Photocatalytic Sand and Fumed Silica for Environmental Remediation. Water Air Soil Pollut. 2014, 225, 1948. [CrossRef]

50. Sugrañez, R.; Cruz-Yusta, M.; Mármol, I.; Martín, F.; Morales, J.; Sánchez, L. Use of industrial waste for the manufacturing of sustainable building materials. ChemSusChem 2012, 5, 694-699. [CrossRef] 
51. Folli, A.; Pade, C.; Hansen, T.B.; De Marco, T.; Macphee, D.E. $\mathrm{TiO}_{2}$ photocatalysis in cementitious systems: Insights into self-cleaning and depollution chemistry. Cem. Concr. Res. 2012, 42, 539-548. [CrossRef]

52. Maggos, T.; Plassais, A.; Bartzis, J.G.; Vasilakos, C.; Moussiopoulos, N.; Bonafous, L. Photocatalytic degradation of $\mathrm{NO}_{\mathrm{x}}$ in a pilot street canyon configuration using $\mathrm{TiO}_{2}$-mortar panels. Environ. Monit. Assess. 2008, 136, 35-44. [CrossRef] [PubMed]

53. Diamanti, M.V.; Ormellese, M.; Pedeferri, M. Characterization of photocatalytic and superhydrophilic properties of mortars containing titanium dioxide. Cem. Concr. Res. 2008, 38, 1349-1353. [CrossRef]

54. Park, S.M.; Chekli, L.; Kim, J.B.; Shahid, M.; Shon, H.K.; Kim, P.S.; Lee, W.S.; Lee, W.E.; Kim, J.H. NO removal of mortar mixed with titania produced from Ti-salt flocculated sludge. J. Ind. Eng. Chem. 2014, 20, 3851-3856. [CrossRef]

55. Vieira, J.; Senff, L.; Gonçalves, H.; Silva, L.; Ferreira, V.M.; Labrincha, J.A. Functionalization of mortars for controlling the indoor ambient of buildings. Energy Build. 2014, 70, 224-236. [CrossRef]

56. Lucas, S.S.; Ferreira, V.M.; De Aguiar, J.A.L.B. Incorporation of titanium dioxide nanoparticles in mortars-Influence of microstructure in the hardened state properties and photocatalytic activity. Cem. Concr. Res. 2013, 43, 112-120. [CrossRef]

57. Vulic, T.; Hadnadjev-Kostic, M.; Rudic, O.; Radeka, M.; Marinkovic-Neducin, R.; Ranogajec, J. Improvement of cement-based mortars by application of photocatalytic active Ti-Zn-Al nanocomposites. Cem. Concr. Compos. 2013, 36, 121-127. [CrossRef]

58. Tasbihi, M.; Bendyna, J.K.; Notten, P.H.L. A short review on photocatalytic degradation of formaldehyde. J. Nanosci. Nanotechnol. 2015, 15, 6386-6396. [CrossRef] [PubMed]

59. Noguchi, T.; Fujishima, A.; Sawunyama, P.; Hashimoto, K. Photocatalytic degradation of gaseous formaldehyde using TiO 2 film. Environ. Sci. Technol. 1998, 32, 3831-3833. [CrossRef]

60. Ince, C.; Derogar, S.; Gurkaya, K.; Ball, R.J. Properties, durability and cost efficiency of cement and hydrated lime mortars reusing copper mine tailings of Lefke-Xeros in Cyprus. Constr. Build. Mater. 2020, 268, 121070. [CrossRef]

61. Palomar, I.; Barluenga, G.; Ball, R.J.; Lawrence, M. Laboratory characterization of brick walls rendered with a pervious lime-cement mortar. J. Build. Eng. 2019, 23, 241-249. [CrossRef]

62. Westgate, P.; Ball, R.J.; Paine, K. Olivine as a reactive aggregate in lime mortars. Constr. Build. Mater. 2019, 195, 115-126. [CrossRef]

63. Westgate, P.; Paine, K.; Ball, R.J. Physical and mechanical properties of plasters incorporating aerogel granules and polypropylene monofilament fibres. Constr. Build. Mater. 2018, 158, 472-480. [CrossRef]

64. El-Turki, A.; Ball, R.J.; Holmes, S.; Allen, W.J.; Allen, G.C. Environmental cycling and laboratory testing to evaluate the significance of moisture control for lime mortars. Constr. Build. Mater. 2010, 24, 1392-1397. [CrossRef]

65. Ball, R.J.; El-Turki, A.; Allen, W.J.; Nicholson, J.A.; Allen, G.C. Deformation of NHL3.5 and CL90/PC hybrid mortars. Proc. Inst. Civ. Eng. Constr. Mater. 2009, 162, 29-35. [CrossRef]

66. Margalha, M.G.; Silva, A.S.; Veiga, M.D.R.; Brito, J.D.; Ball, R.J.; Allen, G.C. Microstructural changes of lime putty during aging. J. Mater. Civ. Eng. 2013, 25, 1524-1532. [CrossRef]

67. Serrapede, M.; Pesce, G.L.; Ball, R.J.; Denuault, G. Nanostructured Pd hydride microelectrodes: In situ monitoring of pH variations in a porous medium. Anal. Chem. 2014, 86, 5758-5765. [CrossRef]

68. Grant, J.; Pesce, G.L.; Ball, R.J.; Molinari, M.; Parker, S.C. An experimental and computational study to resolve the composition of dolomitic lime. RSC Adv. 2016, 6, 16066-16072. [CrossRef]

69. Pesce, G.L.; Fletcher, I.W.; Grant, J.; Molinari, M.; Parker, S.C.; Ball, R.J. Carbonation of Hydrous Materials at the Molecular Level: A Time of Flight-Secondary Ion Mass Spectrometry, Raman and Density Functional Theory Study. Cryst. Growth Des. 2017, 17, 1036-1044. [CrossRef]

70. El-Turki, A.; Carter, M.A.; Wilson, M.A.; Ball, R.J.; Allen, G.C. A microbalance study of the effects of hydraulicity and sand grain size on carbonation of lime and cement. Constr. Build. Mater. 2009, 23, 1423-1428. [CrossRef]

71. Sharma, G.; Bala, R. Digital Color Imaging Handbook; CRC Press: Boca Raton, FL, USA, 2017.

72. Sharma, G.; Wu, W.; Dalal, E.N. The CIEDE2000 color-difference formula: Implementation notes, supplementary test data, and mathematical observations. Color Res. Appl. 2005, 30, 21-30. [CrossRef]

73. Despotou, E.; Shtiza, A.; Schlegel, T.; Verhelst, F. Literature study on the rate and mechanism of carbonation of lime in mortars/Literaturstudie über Mechanismus und Grad der Karbonatisierung von Kalkhydrat im Mörtel. Mauerwerk 2016, 20, 124-137. [CrossRef]

74. Rouquerol, J.; Rouquerol, F.; Llewellyn, P.; Maurin, G.; Sing, K.S.W. Adsorption by Powders and Porous Solids: Principles, Methodology and Applications; Academic Press: Cambridge, MA, USA, 2013.

75. BCB. Enduit mince chaux aérienne pour dressement et finition intérieurs, 80 teintes. Tradic. Décor 2016, 09, 1-3.

76. BSI. EN 196-1: 2016, Methods of Testing Cement, Determination of strength. Br. Stand. Inst. 2016. Available online: https: / / shop.bsigroup.com/ProductDetail/?pid=000000000030291447 (accessed on 24 February 2021).

77. International Organization for Standardization. Determination of the Specific Surface Area of Solids by Gas Adsorption: BET Method. In Technical Committees ISO/TC 24 Particle Characterization Including Sieving. SC 4, Part. Charact, Geneva, Switzerland; 2010; Available online: https:/ / www.iso.org/committee/47166.html (accessed on 24 February 2021).

78. ČSN, E.N. 1015-12: 2000 Methods of test for mortar for masonry-Part 12: Determination of adhesive strength of hardened rendering and plastering mortars on substrates. In Test Methods; BSI: London, UK; ISBN 058034890 3. Available online: https: / / shop.bsigroup.com/ProductDetail/ ?pid=000000000030015539 (accessed on 22 December 2020). 
79. International Organization for Standardization. ISO 22197-1: Fine Ceramics (Advanced Ceramics, Advanced Technical Ceramics)—Test Method for air-purification Performance of Semiconducting Photocatalytic Materials_Part 1: Removal of Nitric Oxide; No. 22197-1; ISO: Geneva, Switzerland, 2007.

80. International Organization for Standardization. ISO 18560:1 Fine Ceramics (Advanced Ceramics, Advanced Technical Ceramics)—Test Method for Air-Purification Performance of Semiconducting Photocatalytic Materials by Test Chamber Method under Indoor Lighting Environment_Part 1: Removal of Formaldehyde; ISO: Geneva, Switzerland, 2014. 